\title{
Inhibitors of mammalian $\mathbf{G}_{1}$ cyclin-dependent kinases
}

\author{
Charles J. Sherr ${ }^{1}$ and James M. Roberts ${ }^{2}$ \\ ${ }^{1}$ Howard Hughes Medical Institute, Department of Tumor Cell Biology, St. Jude Children's Research Hospital, Memphis, \\ Tennessee 38104 USA; $^{2}$ Department of Basic Sciences, Fred Hutchinson Cancer Research Center, Seattle, Washington \\ 98104 USA
}

Biologic machines need brakes, and the nature and fidelity of their operation cannot be unraveled without some prior understanding of how accelerators work. The discovery of mammalian $G_{1}$ cyclins just 4 years ago and the identification of their associated cyclin-dependent kinases (cdks) provided key insights soon thereafter as to how progression through the first gap phase $\left(G_{1}\right)$ of the mammalian cell cycle might be regulated positively. Within the past 18 months, we have begun to learn something about the negative regulators-cdk inhibitors-that constrain their action.

\section{Targets of $G_{1}$ cdk inhibitors: $G_{1}$ cyclin-dependent} kinases

The commitment of cells to enter the DNA synthetic (S) phase of the cell cycle occurs at a restriction $(R)$ point late in $G_{1}$ phase, after which mitogenic growth factors are no longer required for cells to complete division (Pardee 1989|. Cells initiate DNA synthesis 1-3 hr after passing the $\mathrm{R}$ point, indicating that the decision to enter $\mathrm{S}$ phase and the actual onset of DNA replication are separately controlled events. At least in part, both are governed by $G_{1}$ cyclins, which assemble with cdks to form functional holoenzymes whose phosphorylations of key substrates facilitate these transitions (for review in greater detail, see Pines 1993; Sherr 1993, 1994a, and summarized briefly below).

As cells enter the cycle from quiescence $\left(G_{0}\right)$, D-type cyclins and cyclin $E$ are synthesized sequentially during the $\mathrm{G}_{1}$ interval (Koff et al. 1991; Lew et al. 1991; Matsushime et al. 1991), both being rate-limiting for S-phase entry (Ohtsubo and Roberts 1993; Quelle et al. 1993; Resnitzky et al. 1994) (Fig. 1). Genes encoding D-type cyclins (D1, D2, and D3), progressively induced as part of the delayed early response to mitogenic stimulation, are expressed in a cell lineage-specific fashion. Because cells synthesize different combinations of D-type cyclins, none is likely to be essential for $G_{1}$ progression. Their assembly with cdk4 and cdk6 (Matsushime et al. 1992; Bates et al. 1994a; Meyerson and Harlow 1994) is regulated post-translationally by mitogens (Matsushime et al. 1994), and once assembled, cyclin D-bound cdks must be phosphorylated on a single threonine residue by a cdk- activating kinase (CAK) to acquire catalytic activity (Kato et al. 1994b; Matsuoka et al. 1994) (Fig. 1). D-type cyclins are short-lived proteins $\left(t_{1 / 2}<25 \mathrm{~min}\right)$; therefore, withdrawal of growth factors during $G_{1}$ phase prevents their steady accumulation and correlates with the failure of growth factor-deprived cells to progress past the $R$ point. In contrast, their destruction later in the cell cycle is without effect (Matsushime et al. 1991). Therefore, a cardinal property of the D-type cyclins is their regulation by extracellular signals, as opposed to cyclins E, A, and B whose expression during the cell cycle is periodic.

Cyclin D-dependent cdk4 and cdk6 activity are first detected in mid-G $G_{1}$ phase and increase as cells approach the $\mathrm{G}_{1}$ /S boundary (Matsushime et al. 1994; Meyerson and Harlow 1994). Unlike other known cdks, cyclin $\mathrm{D}$-dependent kinases have a distinct substrate preference for the retinoblastoma protein $(\mathrm{pRb})$ over histone $\mathrm{Hl}$ (Matsushime et al. 1992), reflecting the ability of D cyclins to bind to pRb directly (Dowdy et al. 1993; Ewen et al. 1993; Kato et al. 1993). Several lines of evidence suggest that $\mathrm{pRb}$ is a key physiologic substrate of cdk 4 and cdk6 (see below), although other cdks may contribute to $\mathrm{pRb}$ phosphorylation later in the cycle. In turn, $\mathrm{pRb}$ binds to and negatively regulates transcription factors, such as E2F, whose activities are required for S-phase entry (Nevins 1992; Hinds and Weinberg 1994; Sherr 1994b). pRb phosphorylation at or near the $R$ point cancels its growth-suppressive function, releasing these transcription factors from pRb constraint and enabling them to activate genes whose products are necessary for S-phase entry (Fig. 1).

Cyclin E is expressed periodically at maximum levels near the $G_{1} / S$ transition, assembling with a distinct catalytic subunit, cdk2 (Dulic et al. 1992; Koff et al. 1992) (Fig. 1). The latter must also be activated by CAK to yield a functional holoenzyme (Fisher and Morgan 1994; Makela et al. 1994 and references therein). Recent biochemical data suggest that cyclin E might also activate cdk3 (Harper et al. 1995), a catalytic subunit closely related to cdk2, which also plays a putative role in $\mathrm{G}_{1}$ exit (van den Heuvel and Harlow 1993). In Drosophila, cyclin $E$ is essential for completion of $G_{1}$ and entry into $S$ phase (Knoblich et al. 1994). Evidently it regulates a transition different from that promoted by cyclin D1, because cy- 


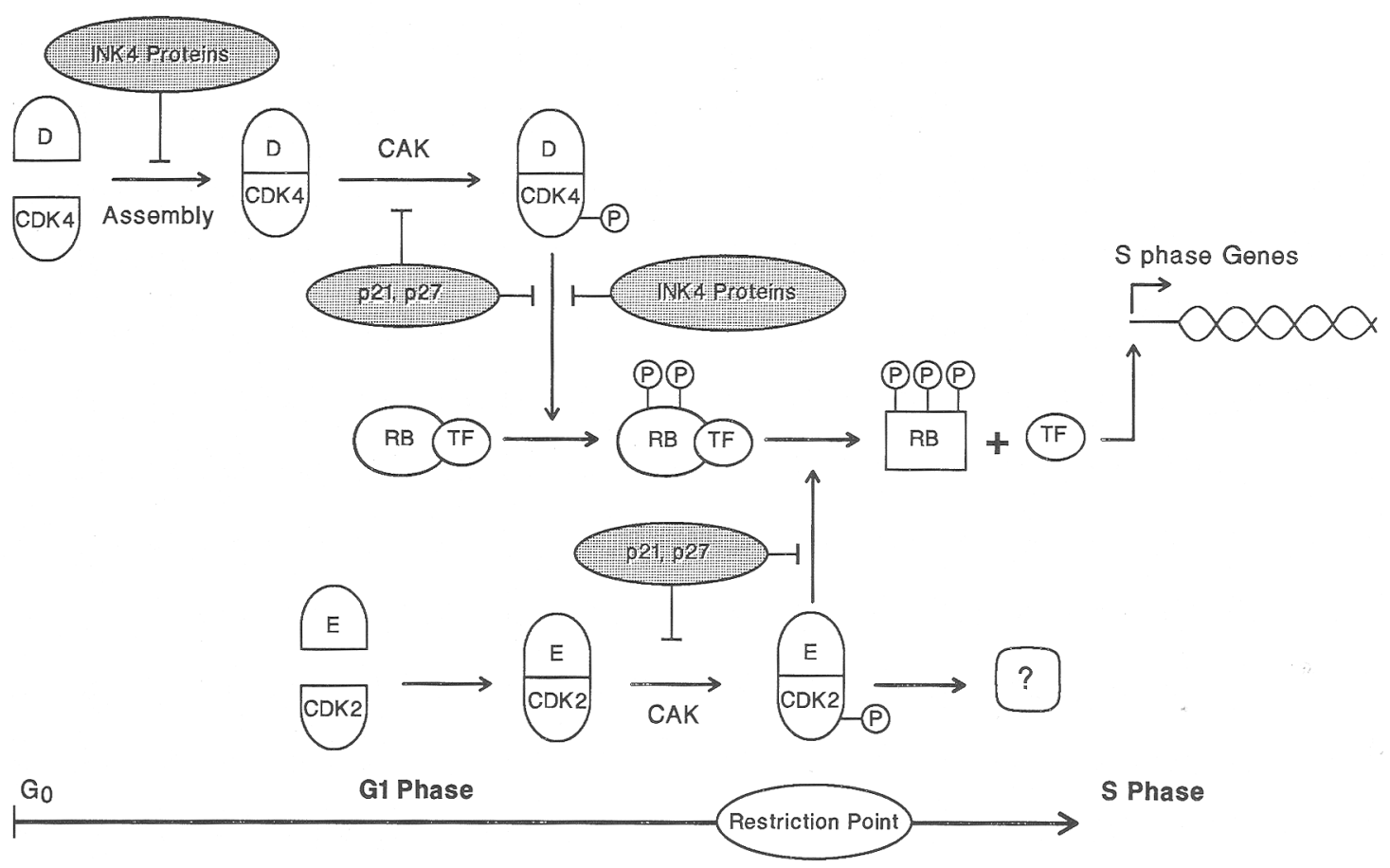

Figure 1. Positive and negative regulators of $G_{1}$ progression. The length of $G_{1}$ is designated by the arrow at the bottom with the restriction $(R)$ point indicated. Early in $G_{1}$, mitogens activate synthesis of D-type cyclins that assemble with cdk4 or cdk6 (the latter not shown). In cells in which ectopic expression of both cyclin D and cdk4 are enforced, their assembly remains growth factor dependent, implicating an unknown regulator ("assembly factor") in the process (Matsushime et al. 1994). Cyclin E is expressed later in $\mathrm{G}_{1}$ phase than $\mathrm{D}$-type cyclins and forms complexes with cdk2. Both classes of complexes require CAK-mediated phosphorylation to become catalytically active. D-type (and likely E-type) cdks are shown to phosphorylate pRb sequentially, releasing bound transcription factors (TFs) such as E2F, which activate genes required for S-phase entry. Cyclin E-cdk2 is also suggested to phosphorylate other substrates to regulate a separate transition. In principle, cyclin D and E could both contribute to $\mathrm{R}$ point control; cyclin E-dependent kinases might trigger the onset of $S$ phase. When expressed in $G_{1}$ phase, Ink4 (INK4) proteins can compete with $D$ cyclins for cdk4 and cdk6 to form independent binary complexes and can inhibit the catalytic activity of the assembled, CAK-modified complexes. In binding to cyclin-bound cdks, p27 and p21 can also work at two points to interfere sterically with CAK-mediated activation and to extinguish the activities of the CAK-modified holoenzymes.

clin E, but not D1 (Lukas et al. 1994, 1995a; Tam et al. $1994 \mathrm{~b} \mid$, is essential for entry into $S$ phase in mammalian cells lacking functional pRb (Ohtsubo et al. 1995). In rodent fibroblasts engineered to express inducible cyclin D1 or cyclin E (Resnitzky et al. 1994), induction of cyclin $\mathrm{D} 1$ triggers rapid $\mathrm{pRb}$ phosphorylation but cyclin $\mathrm{E}$ does not (Resnitzky and Reed 1995). In collaboration with cyclin D-dependent kinases, however, the cyclin E-cdk2 complex may contribute to $\mathrm{pRb}$ phosphorylation late in $\mathrm{G}_{1}$ (Hinds et al. 1992; Hatakeyama et al. 1994), and it likely phosphorylates other key substrates, perhaps acting to trigger the actual onset of DNA replication once cells pass the $\mathrm{R}$ point (Fig. 1).

The identification of D- and E-type cyclins and their associated cdks led to vigorous efforts to define the basis of their regulation. Arguably, among the most exciting recent findings have been the discoveries of novel mammalian $\mathrm{G}_{1}$ cdk inhibitors, whose newly unveiled functions are now helping to explain how antiproliferative signals arrest cells in $G_{1}$ to enable such diverse processes as repair of DNA damage, terminal differentiation, and ceil senescence.

\section{p21 (Cip1, Waf1, Sdi1, Cap20)}

In normal fibroblasts, the majority of cdks are gathered into quaternary complexes that contain, in addition to a cyclin and a cdk, the proliferating cell nuclear antigen [(PCNA) a subunit of DNA polymerase- $\delta($ pol- $\delta$ ); see below) and a protein of $M_{\mathrm{r}} 21,000, \mathrm{p} 21$ (Xiong et al. 1992; Zhang et al. 1993). The p21 protein binds directly to cdc2 (cdk1), cdk2, and cdk4 (Harper et al. 1993; Xiong et al. 1993a,b; Zhang et al. 1993; Dulic et al. 1994) and coprecipitates with them in enzymatically active complexes formed with cyclins $A, B, D$, and $E$ isolated from nontransformed cells (Xiong et al. 1993a; Zhang et al. 1993, 1994). Molecular cloning of $\mathrm{p} 21$, reconstitution of the purified protein with cyclin-cdk complexes in vitro, and its enforced expression in mammalian cell lines revealed that it can act as a potent and universal inhibitor of $\mathrm{cdk}$ enzyme activity that is capable of inducing cell cycle arrest (El-Deiry et al. 1993; Y. Gu et al. 1993; Harper et al. 1993; Xiong et al. 1993b; Noda et al. 1994).

The ability of p21 to inhibit cyclin-cdk activity appears to be ai ududs with its presence in must, if not aii, 
cyclin-cdk complexes in normal cycling cells. p21 is induced when quiescent fibroblasts and $\mathrm{T}$ lymphocytes are stimulated to proliferate by mitogenic signals (Firpo et al. 1994; Y. Li et al. 1994; Noda et al. 1994; Nourse et al. 1994; Sheikh et al. 1994). This apparent paradox is resolved by observations that p21-cyclin-cdk complexes harvested from proliferating cells retain kinase activity that is extinguished by addition of more p21 (Zhang et al. 1994; Harper et al. 1995). Therefore, conversion of active complexes to inactive ones is achieved by changing the ratio of $\mathrm{p} 21$ to cyclin-cdk, such that active complexes contain a single p21 molecule, whereas inactive ones include multiple p21 subunits. Induction of p21, or diminution of cyclin-cdk levels, could lead to cell cycle arrest by allowing the amount of cyclin-cdk complexes in the cell to fall below an inhibitory threshold imposed by p21. It remains unclear, however, whether the single molecule of p21 present in active cyclin-cdk complexes contributes to their function, perhaps by modifying their enzymatic activities in a more subtle manner.

The fact that complexes containing p21 and cyclincdks also include PCNA (see above) suggests that p21 might coordinate the effects of cdks on cell cycle progression with processes of DNA replication and/or repair (Fig. 2). p21 contacts PCNA independently, and inclusion of PCNA has no apparent effect on the inhibition of cyclin-bound cdks by p 21 (Zhang et al. 1994). Using an SV40-based DNA replication system to study the effects of PCNA on DNA replication in vitro, p21 was found to block the ability of PCNA to activate DNA pol- $\delta$ (FloresRozas et al. 1994; Waga et al. 1994). PCNA and p21 interact with one another directly, and the effect of p21 is to impede the processive movement of pol- $\delta$ during DNA chain elongation without affecting the assembly of the PCNA-containing pol- $\delta$ holoenzyme. Although PCNA is also required for nucleotide excision repair of DNA, this process is unaffected by p21 (R. Li et al. 1994; Shivji et al. 1994|. In principle, the interaction of p21 with PCNA might facilitate a proper balancing of the DNA replication and repair machinery throughout the cell cycle.
The cdk-inhibitory and PCNA-binding domains of $\mathrm{p} 21$ are functionally distinct and reside in the amino-terminal and carboxy-terminal halves of the molecule, respectively (Chen et al. 1995; Luo et al. 1995; Nakanishi et al. 1995; Warbrick et al. 1995). The entire human p21-coding sequence is 164 amino acids in length, and residues 1-71 alone are highly active in inhibiting both cdk activity and DNA synthesis in transfected human fibroblasts (Nakanishi et al. 1995). Conversely, a 20-amino-acid peptide comprising residues $141-160$ binds PCNA very efficiently and inhibits SV40 DNA replication in vitro at micromolar concentrations only 10-fold higher than those required for the full-length protein (Warbrick et al. 1995).

Despite the compelling nature of results emanating from experiments using in vitro systems, it is important to discern which structural features of p2l are responsible for growth arrest and for inhibition of DNA replication in vivo. In Xenopus extracts, replication of doublestranded DNA was blocked efficiently only by the cdkinhibitory domain of $\mathrm{p} 21$ at concentrations similar to those of cyclin E-cdk2 (Chen et al. 1995). p21 interrupts an early step of DNA synthesis in this system, but not the elongation of preassembled replication forks, and the replication block could be overcome by addition of cyclins E or A, but not cdk2 or PCNA (Strausfeld et al. 1994). Therefore, cyclin-cdk2 complexes rather than PCNA are limiting and selectively targeted by $\mathrm{p} 21$. In agreement, introduction of the amino-terminal but not the carboxy-terminal domain of p21 suppressed colony formation by p53-negative human Saos-2 osteosarcoma cells (Chen et al. 1995). In transient assays, however, transfection of either the amino- or carboxy-terminal domains of p21 leach tagged with an SV40 T antigen nuclear localization signal) into mink lung cells significantly inhibited cellular DNA synthesis, although the carboxy-terminal segment was relatively less efficient (Luo et al. 1995). Deletion of amino acids 66-71 from the amino-terminal moiety of $\mathrm{p} 21$ resulted in a protein that lacked cdk2 inhibitory activity in vitro but retained the ability to inhibit DNA synthesis in p53-negative human

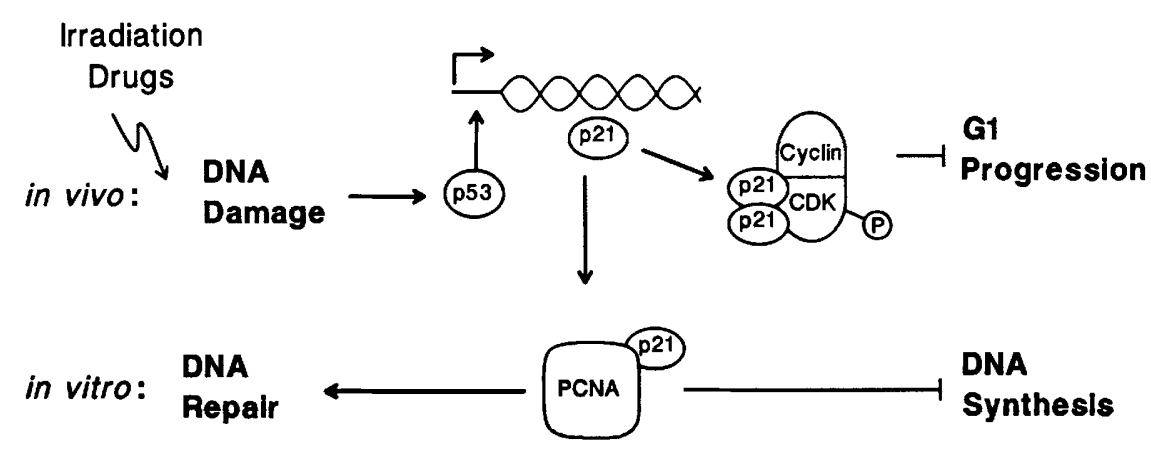

Figure 2. Induction of $\mathrm{p} 21$ by $\mathrm{p} 53$ causes cell cycle arrest and inhibits DNA replication. In response to DNA-damaging agents, p53 levels increase, resulting in induction of p21. p21 forms independent complexes with cyclin-cdks to inhibit their activity and with PCNA, a subunit of pol- $\delta$, to prevent processive DNA synthesis in vitro. In contrast, p21 does not inhibit the role of PCNA in DNA repair. Both effects may contribute to $G_{1}$ arrest at "the p53 checkpoint." Because $G_{1}$-specific cdks are inhibited in vivo, $\mathrm{pRb}$ remains unphosphorylated. Certain cell types execute an alternative program leading to programmed cell death, which appears to depend on other functions of p53 (most likely including other p53-regulated genes). 
fibroblasts (Nakanishi et al. 1995), again suggesting that some of the observed growth inhibitory effects may be attributable to the p21 PCNA-binding domain. In all cases, it appears that the cdk-binding domain of $\mathrm{p} 21$ is more potent at blocking cell cycle progression than is the PCNA-binding domain, although both can clearly inhibit DNA synthesis when present at sufficiently high levels. In vivo, the amount of p21 induced by DNA damage is sufficient to block cdk activity, but it remains to be determined whether its level rises high enough to block the replicative functions of PCNA.

In fibroblasts transformed by DNA tumor viruses or in those derived from p53-deficient Li-Fraumeni patients, newly synthesized p21 and PCNA were no longer detected in association with cyclin-bound cdks, suggesting that expression of functional p53 might somehow facilitate the formation of these higher order complexes (Xiong et al. 1993a). Previously the p53 protein was recognized to induce $\mathrm{G}_{1}$-phase arrest (Martinez et al. 1991) in response to DNA damage (Kastan et al. 1991; Kuerbitz et al. 1992), and its loss or inactivation can promote chromosomal instability (Kastan et al. 1992; Livingstone et al. 1992; Yin et al. 1992; Lu and Lane 1993). Using a subtractive hybridization approach to identify p53-responsive genes, El-Deiry and co-workers (1993) fingered the p2l gene as a p53-responsive element, implying that it may be a central mediator of $p 53$-induced $G_{1}$ checkpoint control (Fig. 2). In agreement, DNA-damaging agents, which stabilize indirectly and thereby increase the levels of $\mathrm{p} 53$ protein in cells, induce p 21 synthesis, leading to further binding of $\mathrm{p} 21$ to cyclin-cdk complexes and to their reduced kinase activity (Di Leonardo et al. 1994; Dulic et al. 1994; El-Deiry et al. 1994). The ability of p21 to inhibit both the cyclin D- and E-dependent kinases can explain why $\gamma$-irradiated cells arrest in $\mathrm{G}_{1}$ phase with hypophosphorylated pRb /cf. Slebos et al. 1994). Through its independent effects on PCNA, p21 induction is also presumed to inhibit DNA replication without affecting DNA repair (Fig. 2). However, in cells harboring mutant p53, p21 is not similarly induced and its basal level of expression in cycling cells is diminished. Importantly, cells lacking functional p 53 would have an increased probability of replicating damaged DNA, thereby increasing their likelihood of acquiring other chromosomal abnormalities and, therefore, predisposing them toward tumor development.

As an alternative and decidedly more dramatic defense against DNA damage, cells can undergo programmed cell death. Induction of apoptosis under these circumstances depends at least in part on p53 (Kastan et al. 1991; Yonish-Rouach et al. 1991; Kuerbitz et al. 1992; Clarke et al. 1993; Lotem and Sachs 1993; Lowe et al. 1993), which could potentially operate by inducing "death genes" (Kastan et al. 1992) or by repressing genes necessary for cell survival (Caelles et al. 1994). Cell cycle arrest caused by enforced $\mathrm{p} 21$ expression need not trigger a suicide program, nor does $\mathrm{p} 53$-dependent apoptosis require p21-induced cell cycle arrest in $\mathrm{G}_{1}$ phase (Caelles et al. 1994; Wagner et al. 1994; Canman et al. 1995). The dependency of apoptosis on p $\overline{5} \overline{3}$ is retained in p $\overline{\mathrm{K}} \mathrm{b}-\mathrm{neg}$ - ative cells, implying that $\mathrm{p} 53$ provides an important safeguard against the loss of the growth-suppressive function of $\mathrm{pRb}$ (Debbas and White 1993; Lowe et al. 1994; Morgenbesser et al. 1994; Pan and Griep 1994; Qin et al. 1994; Symonds et al. 1994; Wu and Levine 1994).

Important insights into p21 function stem from its independent isolation by a completely different approach. By transfecting cDNAs from libraries prepared from senescent human fibroblasts into younger, cycling cells and scoring the transfected cells for their inability to replicate their chromosomal DNA, three senescent-derived inhibitors (Sdi genes) were isolated, one of which (Sdil) proved to encode p21 (Noda et al. 1994). Expression of p21 increased 10- to 20-fold in senescing fibroblasts, paralleling their loss of proliferative capacity. Inactive cyclin E-cdk2 and cyclin D1-cdk2 complexes also accumulate in senescent cells (Dulic et al. 1993), and the former complexes may well be held in check by $\mathrm{p} 21$. Whereas cyclins D2 and D3 can activate cdk2, it appears that cyclin Dl-cdk2 complexes remain catalytically inert (Ewen et al. 1993a), possibly because they are not activated by CAK (Dulic et al. 1993; Bates et al. 1994a). In this setting cyclin Dl might itself act as a cdk inhibitor.

During mouse development, p21 mRNA, visualized by in situ hybridization, is localized in a highly selective manner to tissues that primarily contain postmitotic differentiated cells (Parker et al. 1995). This is particularly manifest in differentiating skeletal muscle, where p 21 is coexpressed temporally with myogenin. Muscle differentiation is blocked in mice lacking myogenin (Hasty et al. 1993), but their undifferentiated myoblasts express p21 and exit the cell cycle normally. Although p21 induction may be essential for $G_{1}$-phase arrest in response to DNA damage, the fact that it can be expressed at high levels in p53-negative cells indicates that the gene must also be regulated independently by other transcription factors (Jiang et al. 1994; Michieli et al. 1994; Sheikh et al. 1994; Parker et al. 1995).

Induction of $\mathrm{p} 21$ has also been observed in cultured hematopoietic cell lines undergoing differentiation (Jiang et al. 1994; Steinman et al. 1994). Paralleling the results obtained with muscle cells in vivo, p21 mRNA and protein synthesis are induced during differentiation of cultured myoblasts, preceding the expression of muscle differentiation markers such as myosin light chain, and correlating with the withdrawal of the cells from the cycle (Halevy et al. 1995). In myoblasts shifted to medium containing a low concentration of serum, the skeletal muscle-specific transcriptional regulator, MyoD, was found to activate $\mathrm{p} 21$ gene expression in a p53-independent manner, in accord with the ability of MyoD to induce cell cycle arrest. Transfection of undifferentiated myoblasts with the p21 gene for with the specific cyclin D-dependent kinase inhibitor, pl $6^{\text {INK4a }}$; see below) increased muscle-specific gene expression, even in cells maintained under nondifferentiating conditions in high serum. Conversely, the enforced expression of cyclin D1, but not cyclins E, A, or B, prevented MyoD from activating the expression of muscie-specific genes $(\bar{K}$ ao et ai. 
1994; Skapek et al. 1995). Thus, active cyclin D-dependent kinases both enforce $G_{1}$ progression and suppress MyoD function in proliferating cultured myoblasts grown in high serum (Fig. 3A). A highly phosphorylated form of MyoD was detected under conditions where differentiation is precluded, but the significance of these modifications remains unclear and the kinases responsible for them have not been identified. Shifting these cells to medium containing low serum would reduce mitogen-responsive cyclin D-cdk activity, activating sequentially both MyoD and p21 and thereby ensuring the continued activity of MyoD as the growth-arrested cells differentiate (Halevy et al. 1995; Skapek et al. 1995) (Fig. $3 \mathrm{~B})$. Given that the loss of $\mathrm{pRb}$ function prevents the normal $G_{0}$ arrest observed in differentiated skeletal muscle (W. Gu et al. 1993; Thorburn et al. 1993; J. Schneider et al. 1994), it seems likely that cyclin D-dependent kinases play a central role in inactivating both $\mathrm{MyoD}$ and pRb. Direct physical interactions between the latter two proteins have been reported (W. Gu et al. 1993), which, at least in principle, could help to coordinate their action.

\section{p27 (Kip1) and p57 (Kip2)}

Mink MvlLu lung epithelial cells arrest in $G_{1}$ phase when grown to high density, and their entry into $S$ phase is prevented if they are released from contact inhibition in the presence of transforming growth factor- $\beta$ (TGF- $\beta$ ). Although contact-inhibited or TGF- $\beta$-treated cells express cyclin E-cdk 2 complexes, cyclin E-associated kinase activity cannot be detected (Koff et al. 1993). Extracts prepared from such cells contained saturable quan- tities of a heat-stable cyclin E-cdk2 inhibitor, whose activity could be overcome by addition of supraphysiologic quantities of recombinant cyclin E (Polyak et al. 1994a). If instead, cyclin D-cdk4 complexes were added to inhibitory extracts from TGF- $\beta$-arrested or contactinhibited cells, subthreshold levels of cyclin E proved capable of activating cdk2. Mutant, catalytically inactive cyclin D-cdk4 complexes were equally effective in reversing the effects of the inhibitor on cyclin E-cdk2, suggesting that the cyclin D-cdk4 complexes acted stoichiometrically in binding and sequestering the inhibitory components in the extracts. The inhibitor bound efficiently to cyclin-cdk complexes, but not to cdks alone, and its purification from boiled cell lysates by chromatographic methods and affinity chromatography on cyclin E-cdk2 matrices led to the identification of a single $M_{\mathrm{r}} 27,000$ polypeptide designated kinase inhibitory protein-1 (Kip1) (Polyak et al. 1994a).

Microsequencing of purified p27 and molecular cloning of genes encoding the protein from mink, mouse, and human cDNA libraries (Polyak et al. 1994b), as well as isolation of the mouse gene from a "two-hybrid" interactive screen in yeast using cdk4 as "bait" (Toyoshima and Hunter 1994), revealed that p27 and p21 share significant amino acid homology in their amino-terminal domains. A 60-amino-acid segment at the amino-terminal end of human $\mathrm{p} 27$ is $44 \%$ identical to the corresponding sequences of human $\mathrm{p} 21$, and a polypeptide representing this region contained considerable cdk inhibitory on its own (Polyak et al. 1994b). (The analogous segment of p21 is similarly required for its cdk inhibitory activity (see above).] Transfection of expression vectors
A

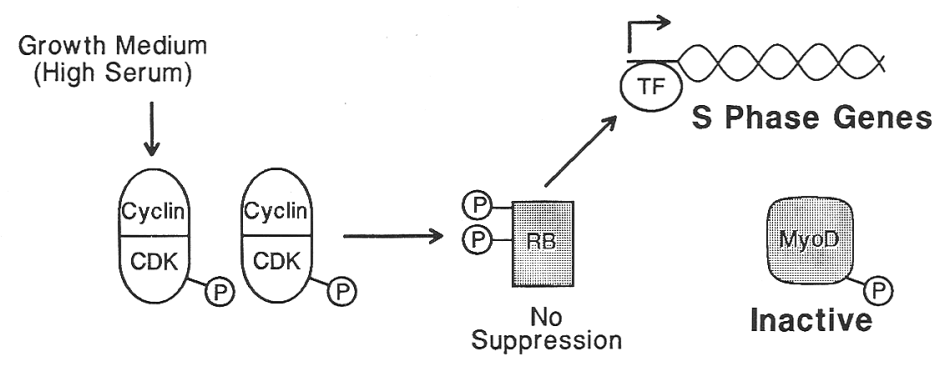

B

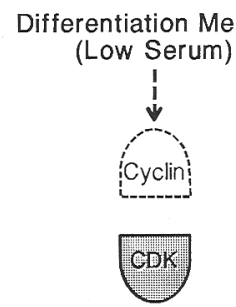

Inactive

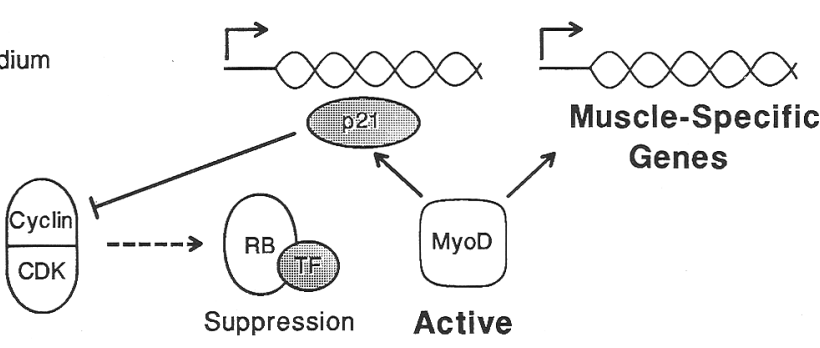

Figure 3. $\mathrm{p} 21$ as a regulator of muscle cell differentiation. (A) Cultured myoblasts propagated in medium containing relatively high serum concentrations remain in cycle and do not differentiate. Cyclin synthesis continues, pRb undergoes periodic phosphorylation, and MyoD is also phosphorylated and remains inactive. It is not known whether MyoD phosphorylation contributes to its inactivity, and the kinases that catalyze this modification have not been identified. For simplicity, only a single site of phosphorylation is indicated in the schematic. Shifting cells to medium containing low serum should decrease the rate of cyclin synthesis, leading to inactivation of at least part of the cyclin-cdk pool $(B)$. Under these conditions, $\mathrm{pRb}$ begins to accumulate in its hypophosphorylated form, and MyoD becomes active. MyoD activates transcriptionally both muscle-specific genes and $\mathrm{p} 21$. Induction of p21 further inhibits cdks, enforcing a positive feedback loop that might ulti-

mately make cell cycle exit irreversible. Terminal differentiation depends on pRb function, and cells lacking functional pRb can reenter the cell division cycle even after expressing muscle-specific genes and forming myotubes. $p R b$ has been reported to regulate MyoD through direct physical interactions (W. Gu et al. 1993), these not being indicated in the schematic. The model was adapted from Halevy et al. (1995) and Skapek et al. (1995). 
encoding p27 into mink MvlLu cells or into human Saos- 2 osteosarcoma cells induced $G_{1}$ arrest (Polyak et al. 1994b; Toyoshima and Hunter 1994). Because Saos-2 cells do not express functional pRb and p53, p27-induced arrest must not depend on either of these tumor-suppressor proteins. Like p21, p27 binds more avidly to cyclincdk complexes than to cdks alone and can inhibit the activity of cyclin D-, E-, A-, and B-dependent kinases in vitro. Whereas cyclin D1 and cdk4 were detected in p27 immunoprecipitates prepared from proliferating mouse Swiss-3T3 cells, cdc2, cdk2, and cyclins E, A, or B1 were not visualized easily (Toyoshima and Hunter 1994). However, in other proliferating cell types, complexes between $\mathrm{p} 27$ and cyclin E-cdk2 have been detected readily (Hengst et al. 1994; Nourse et al. 1994). The binding of p27 to different cyclin-cdk complexes need not connote selective interactions. Rather, under circumstances where certain cyclin-cdk complexes are more prevalent than others, simple mass action might determine the distribution of p27 among them.

Expression of p27 mRNA in quiescent or proliferating MvlLu cells is invariant, and TGF- $\beta$ treatment does not affect its abundance detectably (Polyak et al. 1994b). More surprising were initial observations that p27 protein levels appeared not to change as cells exited $\mathrm{G}_{0}$ and progressed through the cell cycle (Toyoshima and Hunter 1994). However, it is likely that many established cell lines have "learned" to bypass negative regulatory controls in the process of adaptation to culture. We might anticipate that there would be significant differences in the expression of cdk inhibitors in cstablished cell lines versus diploid strains, or, more problematically for experimentalists, between cultured cells and those in normal tissues. With these caveats in mind, studies in a number of cell systems now suggest that p27 protein levels are subject to considerable post-translational regulation.

Levels of cdk inhibitory activity, attributable at least in part to $\mathrm{p} 27$, are relatively high in quiescent $\mathrm{Mv} 1 \mathrm{Lu}$ epithelial cells and fall as cells progress through $G_{1}$ phase, correlating inversely with the activation of cyclin $\mathrm{E}-\mathrm{cdk} 2$ and directly with the progressive loss of sensitivity to TGF- $\beta$-mediated arrest as cells approach the $\mathrm{G}_{1} / \mathrm{S}$ boundary (Polyak et al. 1994a; Slingerland et al. 1994). In cultured macrophages dependent on colonystimulating factor-1 (CSF-1) for $G_{1}$ progression, p27 levels are elevated in arrested CSF-1-deprived cells and decline in response to growth factor stimulation (Kato et al. 1994a). Analogs or inducers of cAMP prevent $G_{1}$ progression in CSF-1 stimulated macrophages, arresting the cells in mid- $G_{1}$, and although cyclin D1-cdk4 complexes assemble normally in cAMP-treated cells, they remain catalytically inactive. Inducers of cAMP increase the overall level of p27, and more p27 accumulates in complexes with cyclin D1-cdk4. Under these circumstances, CAK is blocked by cdk4-bound p 27 from accessing and activating the kinase, underscoring the capability of p27 to inhibit not only fully functional cyclin-cdk complexes but also to interfere physically with their activation by CAK (see Fig. 1) (Kato et al. 1994a; Polyak et al. 1994b). p27 also accumulates in quiescent human fibroblast strains and in HeLa cells arrested in $G_{1}$ phase by treatment with lovastatin (Hengst et al. 1994; Nourse et al. 1994). However, some of the cyclin E-cdk2 inhibitory activity detected in quiescent diploid fibroblasts can be attributed to other molecules (Ohtsubo et al. 1995). In yet another setting involving mitogenic activation of normal peripheral blood $\mathrm{T}$ cells, formation of functional cyclin-cdk 2 complexes does not occur in the absence of interleukin-2 (IL-2), and quiescent cells, as well as those stimulated by the antigen receptor to enter but not progress through $G_{1}$ phase, express very high levels of p27 (Firpo et al. 1994; Nourse et al. 1994). Whereas antigen receptor signaling promotes the synthesis of cyclin D2cdk, E-cdk, and A-cdk complexes (Ajchenbaum et al. 1993; Firpo et al. 1994; Modiano et al. 1994), stimulation by IL-2 leads to the rapid elimination of p27, facilitating activation of the assembled $\mathrm{G}_{1}$ phase cdks and entry into $S$ phase (Nourse et al. 1994). Conversely, the immunosuppressant rapamycin inhibits $G_{1}$ progression by preventing the IL-2-mediated decline in p27 levels. Interestingly, rapamycin also prevents the IL-2-dependent accumulation of $\mathrm{p} 21$, consistent with the idea that $\mathrm{p} 21$ performs an essential function in cycling cells /see above). These results provide a mechanistic explanation for why two distinct extracellular signals may be required for the $G_{0}$ to $S$-phase transition in normal peripheral blood $\mathrm{T}$ cells. A similar mechanism might explain analogous phenomena in normal fibroblast stains where the combined action of so-called competence and progression factors is also required (Pardee 1989).

The latter findings also highlight a major difference between $\mathrm{p} 21$ and $\mathrm{p} 27$ during the initial response to growth factor stimulation. Namely, whereas p27 tends to accumulate in quiescent cells and declines in response to mitogenic stimulation, p21 levels are generally low in quiescent cells but rise in response to mitogen treatment. Because p21 levels remain elevated in irreversibly postmitotic or nondividing senescent cells /see preceding section), these states of growth arrest differ from that of quiescent cells, which retain a proliferative capacity.

Although the amount of p27 falls significantly during the $\mathrm{G}_{0}$ to $S$-phase transition, it continues to be synthesized in proliferating cells, leaving the possibility open that its expression might also be regulated periodically. In HeLa cells synchronized in M phase with nocodazole, or in elutriated HL60 leukemia cells in which cell size correlates with cell cycle position, p27 levels were found to be highest in $\mathrm{G}_{1}$-enriched fractions and declined as cyclin E accumulated (Hengst et al. 1994). Under certain circumstances, p27 can accumulate without an apparent increase in mRNA or protein synthesis; therefore its levels may be controlled by its turnover. However, in other biologic settings, the abundance of p27 mRNA and protein correlate much more closely. Evidently, the levels of p27 can be regulated through a number of different mechanisms.

The expression of both p21 and p27 in cycling cells implies that cyclin-cdk complexes must overcome an inhibitory threshold to become catalytically active 
(Polyak et al. 1994a). As opposed to quiescent cells where p27 is present in excess of cyclin-cdk complexes, cyclincdk levels must exceed those of the inhibitors in cycling cells, and consequently the pools of $\mathrm{p} 27$ and p 21 become sequestered into cyclin-cdk complexes (Toyoshima and Hunter 1994; Zhang et al. 1994; Harper et al. 1995). For cells entering the cycle, the timing of activation of cyclin $D$-dependent kinases in mid- $G_{1}$ phase (Matsushime et al. 1994; Meyerson and Harlow 1994) is consistent with the idea that their kinase activity first becomes manifest as the putative cdk inhibitory threshold is exceeded (Fig. 4A). An important feature of this model is that cyclin D-cdk complexes are perceived to play a dual role in stoichiometrically titrating cdk inhibitors as well as in phosphorylating critical substrates necessary for $G_{1}$ exit. A prediction is that agents that inhibit the formation of cyclin D-cdk complexes selectively might lead to an increase in "free" p21 and p27, thereby inhibiting cyclin E-cdk2 and enforcing $G_{1}$ arrest (Fig. 4B). For example, TGF- $\beta$ inhibits cdk 4 synthesis and assembly with cyclin D (Ewen et al. 1993b, 1995), correlating with the observed p27-mediated inhibition of cyclin E-cdk2 activity (Koff et al. 1993; Polyak et al. 1994a; Slingerland et al. 1994). Effects of this cytokine on cdk4 synthesis may be p53 dependent (Ewen et al. 1995). Conversely, enforced expression of cdk4 renders MvlLu mink lung cells resistant to TGF- $\beta$-induced $G_{1}$-phase arrest (Ewen et al. 1993b). Therefore, threshold levels of expression of cdk inhibitors may set a dependency of cyclin E-cdk2 activation on the prior assembly of cyclin D-dependent kinases, determining the order of phosphorylation of their substrates during $G_{1}$ progression. The model provides a rationale for the continued expression of cdk inhibitors in cycling cells.

In principle, any cdk inhibitor might act as a tumorsuppressor protein (Hunter and Pines 1994). In human leukemias, there is a relatively high incidence of heterozygous deletions at chromosome 12p12-13 involving the KIP1 locus, but the failure to detect mutations within the coding sequences of the remaining alleles in these cases leaves its candidacy as a tumor suppressor uncertain (Bullrich et al. 1995; Pietenpol et al. 1995; PonceCastaneda et al. 1995). Given that relatively small changes in p27 levels are sufficient to arrest the cell cycle, it may be that haploid insufficiency can allow inappropriate proliferation of certain hematopoietic cell types.

A more recently identified cdk inhibitor, $\mathrm{p} 57^{\mathrm{Kip} 2}$, con-
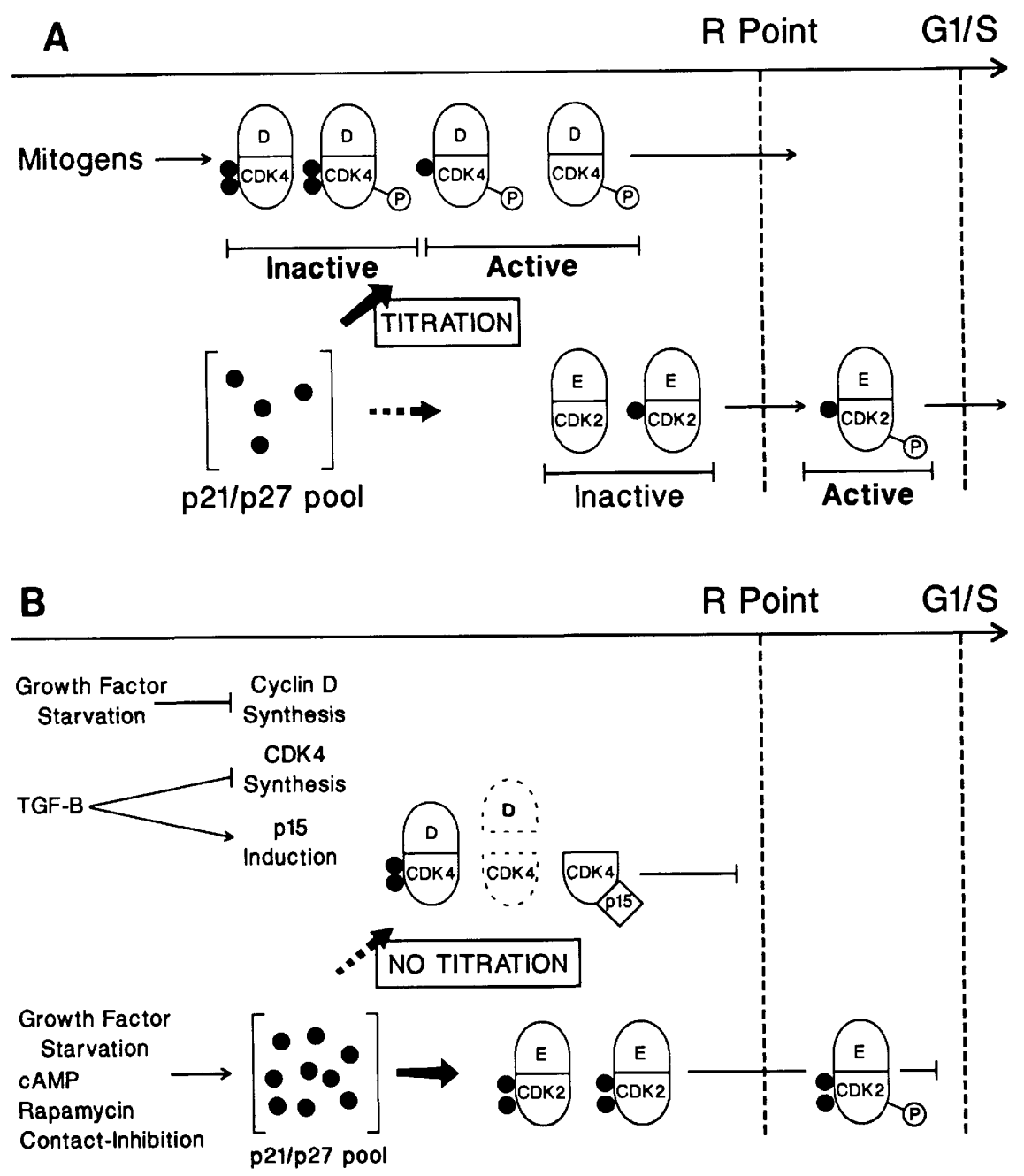

Figure 4. An inhibitory threshold set by p21 and p27. $(A)$ In mitogen-stimulated cells entering the cycle, cyclin D-cdk complexes sequester p21 and p27 molecules. As the amount of cyclin D-cdk complexes exceeds a threshold imposed by the fluctuating levels of the two inhibitors (see text), cyclin D-dependent kinase activity becomes detectable in mid- $\mathrm{G}_{1}$ phase and continues to increase as cells progress toward S phase. Titration of $\mathrm{p} 21$ and $\mathrm{p} 27$ would enable cyclin E-cdk2 complexes to assemble in a functionally active form as cells approach the $G_{1} / S$ boundary, thereby setting a dependence of cyclin E-cdk2 activity on formation of the cyclin D-cdk complexes. Both the stoichiometric and catalytic functions of cyclin D-cdk complexes are proposed to be necessary for $G_{1}$ progression. $(B)$ Extracellular signals can influence the ratio of cdk inhibitors to cyclin-cdk complexes by several independent mechanisms. Growth factor starvation or treatment of cells with TGF- $\beta$ can negatively affect cyclin D or cdk4 synthesis, respectively. In addition, TGF- $\beta$ induces pl $5^{\mathrm{INK} 4 \mathrm{~b}}$, a specific inhibitor of $\mathrm{cy}$ clin D-dependent kinases. Analogs or inducers of cAMP, the immunosuppressant drug rapamycin, and cell contact inhibition prevent the decrease in p27 levels observed in cells treated with mitogens alone. 
tains an amino-terminal cdk inhibitory domain homologous to those present in both p21 and p27, followed by unique proline-rich $(28 \%)$ and acidic segments $137 \%$ glutamic and aspartic acid), and distal carboxy-terminal sequences related to those in p27 (Lee et al. 1995; Matsuoka et al. 1995). In vitro-translated mouse p57 Kip2 bound to $\operatorname{cdk} 2$, cdk3, cdk4, and cdk6 in a cyclin-dependent manner but did not associate with CAK /cdk7-cyclin $\mathrm{H}$ ) or with baculovirus vector-encoded cyclins produced in insect cells. After transfection of MvlLu mink lung cells with tagged p57 molecules and retrieval of p57 from cell lysates, cdk2 and cdk4, as well as cyclins E, A, and D1, were copurified. The $\mathrm{p} 57^{\mathrm{Kip} 2}$ protein can inhibit the kinase activities of cyclin D-cdk4, D-cdk6, E-cdk2, $\mathrm{E}-\mathrm{cdk} 3$, and A-cdk2 complexes in vitro, and its transfection into mink lung cells (Lee et al. 1995) or into human Saos-2 osteosarcoma cells (Matsuoka et al. 1995) induced $\mathrm{G}_{1}$ arrest. As for $\mathrm{p} 27^{\mathrm{Kip} 1}$ (see above), the latter findings indicate that neither $\mathrm{pRb}$ nor $\mathrm{p} 53$ are required for these effects of $\mathrm{p} 57^{\mathrm{Kip} 2}$ on the cell cycle.

Expression of $\mathrm{p} 57^{\mathrm{Kip} 2} \mathrm{mRNAs}$ is more tissue-restricted than that for $\mathrm{p} 27^{\mathrm{Kip} 1}$, with a 1.5 - to $1.7-\mathrm{kb}$ species highly expressed in placenta and at lower levels in skeletal muscle, heart, kidney, lung, pancreas, and brain. An alternatively spliced 6- to 7-kb p57 mRNA was detected in heart (Lee et al. 1995; Matsuoka et al. 1995). Expression of p57, studied in developing mouse embryos by in situ hybridization, was visualized at days $9.5-15.5$ postcoitum in brain, the lens epithelium of the eye, skeletal muscle, and cartilage with the most intense signals being observed in cell types that were not proliferating actively. In tissues such as skeletal muscle and cartilage, the patterns of expression of $\mathrm{p} 57$ overlapped with those of $\mathrm{p} 21$, whereas in other tissues, they were quite different (Matsuoka et al. 1995). The chromosomal localization of human $K I P 2$ is $11 \mathrm{p} 15$, a region that undergoes frequent deletions or rearrangements in many forms of human cancer, in patients with the Beckwith-Weidemann syndrome, which predisposes to rhabdomyosarcoma and other tumors, and in Wilms' tumor (Koufos et al. 1985; Koi et al. 1993, and references therein). A putative tumor-suppressor gene is thought to reside at this locus, and KIP2 represents as reasonable a candidate as any.

\section{p16 $^{\text {INK4a }}$ (MTS1, CDKN2, CDK4I) and the Ink4 family}

In cells transformed by the DNA tumor virus SV40, cdk4 was observed to associate with a protein of $M_{\mathrm{r}} 16,000$ at the expense of D cyclins (Xiong et al. 1993a). The cDNA encoding this protein was isolated using a two-hybrid interaction screen with cdk 4 as bait and was predicted to encode a 148-amino-acid polypeptide primarily composed of four tandemly repeated ankyrin motifs, each $\sim 32$ amino acids in length (Serrano et al. 1993). Recombinant p16 binds to cdk4 or cdk 6 but not to cyclins or other known cdks, forming a binary complex lacking kinase activity. Addition of recombinant p16 to catalytically active cyclin D-cdk4 or cyclin D-cdk6 complexes assembled in insect $S f 9$ cells potently inhibited their $p R b$ kinase activity, whereas p16 was without effect on other cyclin-cdks. Because of its specificity as an inhibitor of cdk4 (and cdk6), the protein was designated Ink4 (now Ink4a).

It was reasoned that the relative abundance of p16 ${ }^{\mathrm{INK} 4 \mathrm{a}}$ and D-type cyclins might determine the activity of the cdk4 kinase in vivo and therefore, regulate $\mathrm{G}_{1}$-phase progression. Enforced expression of $\mathrm{p} 16^{\mathrm{INK} 4 \mathrm{a}}$ in various cell lines induces $\mathrm{G}_{1}$-phase arrest (Guan et al. 1994; Lukas et al. 1995b; Serrano et al. 1995). However, an apparent paradox was the significant elevation in p16 expression observed in tumor cells lacking functional pRb (Xiong et al. 1993a; Okamoto et al. 1994; Otterson et al. 1994; Tam et al. 1994a; Parry et al. 1995). Why should a cdk 4 inhibitor be overexpressed in proliferating cells that lack this tumor-suppressor protein?

Serrano and co-workers (1993) suggested that pRb might represent the sole critical substrate of $\mathrm{D}$-type cdks. Therefore, in cells lacking functional $\mathrm{pRb}$, these kinases would not be required, and the inhibitory function of $\mathrm{p} 16^{\text {INK4a }}$ would not be manifest. Consistent with this hypothesis, overexpression of p16 prevents proliferation in pRb-positive cells but is ineffective in pRb-negative cells (Guan et al. 1994), including embryo fibroblasts derived from Rb-nullizygous mice (Lukas et al. 1995b; Medema et al. 1995). Similarly, microinjected or scrape-loaded antibodies to cyclin D1, although capable of preventing $\mathrm{S}$-phase entry in $\mathrm{pRb}$-positive fibroblasts (Baldin et al. 1993; Quelle et al. 1993) and inhibiting both cyclin $\mathrm{D}-\mathrm{cdk} 4$ activity and $\mathrm{pRb}$ phosphorylation in vivo (Lukas et al. 1995a), are noninhibitory when introduced into either pRb-negative tumor cells (Lukas et al. 1994; Tam et al. 1994b) or into embryo fibroblasts derived from homozygous, pRb-deficient mice (Lukas et al. 1995a). pl $6^{\text {INK4a }}$ can also suppress neoplastic transformation of cultured fibroblasts by $\mathrm{H}-\mathrm{Ras}$ and c-Myc but not by $\mathrm{H}-\mathrm{ras}$ and E1 A (Serrano et al. 1995). Therefore, p16 ${ }^{\mathrm{INK} 4 \mathrm{a}}$ can act upstream of cyclin D-dependent kinases to inhibit their phosphorylation of $\mathrm{pRb}$ (see Fig. 1), and in the absence of $\mathrm{pRb}$ function, overexpression of $\mathrm{pl} 6^{\mathrm{INK} 4 \mathrm{a}}$ or inhibition of cyclin D-dependent kinase does not affect $\mathrm{G}_{1}$-phase progression.

The normal role of $\mathrm{p} 16^{\mathrm{INK} 4 \mathrm{a}}$ in cell cycle control remains enigmatic. Because p16 $6^{\mathrm{INK} 4 a}$ invokes $G_{1}$ arrest only under conditions in which $\mathrm{pRb}$ is present in its hypophosphorylated growth-suppressive form, expression of pl6 in cells that have passed the restriction point should have no deleterious effects on their progression through the $S, G_{2}$, and $M$ phases of the cell cycle (Lukas et al. 1995b). Therefore, it is conceivable that p16 might act to down-regulate cdk4 and cdk6 once pRb has been inactivated by phosphorylation (Serrano et al. 1993), in turn, implying that the activities of these kinases in $S$, $\mathrm{G}_{2}$, or $M$ phase might otherwise be detrimental. The simplest way to guarantee such a function would be to place the INK4a gene under the control of pRb-regulated transcription factors. Alternatively, pl6 might act as a variable resistor, accumulating concomitantly with $\mathrm{pRb}$ phosphorylation and determining the rate. If p16 levels were to rise as $\mathrm{pRb}$ underwent phosphorylation, cyclin 
D-dependent kinases would also need to reach a higher threshold to ensure completion of the process. Therefore, p16 might buffer the system by preventing the premature activation of pRb by small, "accidental" increases in these kinases. Either model predicts that in cycling cells expressing functional $\mathrm{pRb}, \mathrm{p} 16^{\mathrm{INK} 4 \mathrm{a}}$ should be induced in late $G_{1}$ phase (Tam et al. 1994a). Induction of the protein earlier in $G_{1}$, presumably in response to certain antiproliferative signals, would provide a mechanism for invoking $\mathrm{G}_{1}$ arrest.

p16-cdk4 and p16-cdk6 complexes assemble at the expense of cyclin D-cdks in tumor cells lacking functional $\mathrm{pRb}$, either as a result of transformation by DNA tumor viruses or in those in which $\mathrm{pRb}$ is mutated or deleted (Serrano et al. 1993; Xiong et al. 1993a; Bates et al. 1994b; Okamoto et al. 1994; Tam et al. 1994a,b; Parry et al. 1995). Cyclin D1 undergoes rapid turnover whether unbound or bound to cdk4 or cdk6 (Matsushime et al. $1992)$, but the free form is degraded faster $\left(t_{1 / 2}=10 \mathrm{~min}\right.$ ) than the bound species $\left(t_{1 / 2}=25 \mathrm{~min}\right)$ (Bates et al. 1994b). Therefore, in pRb-negative tumor cells where pl6 competes with cyclin D for cdk4 or cdk6, the overall level of cyclin D expression is reduced. Cyclin D1 transcription is also subject to $\mathrm{pRb}$-mediated controls (Müller et al. 1994). If increasing amounts of recombinant pl6 are added to mixtures containing cyclin D and either cdk4 or cdk6, p16 and cyclin D form independent binary complexes with the cdks, suggesting that p16 and cyclin D vie with one another for cdk-binding sites during assembly of the different complexes (Parry et al. 1995). However, if p16 is added to catalytically active cyclin D-cdk complexes preassembled in insect $\mathrm{Sf} 9$ cells, it enters into stable ternary complexes with cyclin D-cdk without displacing the cyclin; nonetheless, the resulting complexes are catalytically inactive (Hirai et al. 1995). Together, these findings suggest that p16 is a not only a bona fide inhibitor of cyclin D-cdk4 holoenzyme activity but can also interfere with cyclin-cdk assembly (see Fig. 1). Because D-type cyclins turn over much more rapidly than either p16 or the cdks in living cells (Matsushime et al. 1992; Parry et al. 1995), it seems likely that D-type cyclins can be replaced progressively by excess p 16 if the balance of expressed D-type cyclin and p16 is shifted in favor of the latter.

Although p16 is generally overproduced in pRb-negative human tumor cells, this may not be the case in mouse embryo fibroblasts containing homozygously disrupted $R B$ alleles. Comparable amounts of cyclin D1 and D2 proteins in complexes with cdk4 were recovered from lysates of $R B^{+1+}$ and $R B^{-1-}$ mouse fibroblasts, and no differences in their kinase activities were observed (Lukas et al. 1995a). These observations could reflect dissimilarities in $\mathrm{pRb}$ function in humans versus mice. Heterozygous $R B^{+1-}$ mice fail to develop retinoblastoma but, instead, acquire $R B^{-1-}$ pituitary tumors later in life arising in cells that have sustained mutations in their second $R B$ allele (Clarke et al. 1992; Jacks et al. 1992; Lee et al. 1992). On the other hand, loss of $R B$ may not be sufficient to guarantee p16 induction, and other events occurring during multistep carcinogenesis might account for the observed elevations in p16 levels in pRbnegative tumor cells. For example, disruption of $\mathrm{pRb}$ function may occur in a biologic setting where p16 levels are already elevated. One might imagine that pl6 (like p21; see abovel is induced as certain cells differentiate terminally and exit the cell cycle, thereby limiting cyclin D-dependent kinase activity and helping to maintain $\mathrm{pRb}$ in its hypophosphorylated growth-suppressive form. Several lines of evidence suggest that $\mathrm{pRb}$ plays an important role in such processes (Coppola et al. 1990; Weinberg 1991; W. Gu et al. 1993; Hamel et al. 1993; Kato \& Sherr 1993; Thorburn et al. 1993; J. Schneider et al. 1994). Under these circumstances, loss of $\mathrm{pRb}$ function would bypass the cdk inhibitory activity of elevated pl6, maintain cells in cycle, and predispose to tumor formation.

Presently, three additional genes related to INK4a have been isolated, all of which encode polypeptides composed of four repeated ankyrin motifs and specifically inhibit the activities of the cyclin D-dependent kinases to induce cell cycle arrest (Guan et al. 1994, 1995; Hannon and Beach 1994; Chan et al. 1995; Hirai et al. 1995). Synthesis of one of these proteins, p1 $5^{\mathrm{INK} 4 \mathrm{~b}}$, is induced in human epithelial ( $\mathrm{HaCaT}$ ) cells by TGF- $\beta$, suggesting that it functions as an effector of cell cycle arrest mediated by this cytokine (Hannon and Beach 1994). Unlike results of previous studies with MvlLu mink lung epithelial cells, TGF- $\beta$ treatment of $\mathrm{HaCaT}$ cells had no effect on cdk4 synthesis. Given that cdk4 overexpression can override TGF- $\beta$-induced $G_{1}$ arrest (Ewen et al. 1993b), formation of p15-cdk4 complexes at the expense of cyclin D-cdk4 would be expected to increase the pool of free $\mathrm{p} 27^{\mathrm{Kip} 1}$, thereby inhibiting cyclin E-cdk2 activity as well (Polyak et al. 1994a; for review, see Peters 1994) (Fig. 4B). mRNAs encoding p15 $5^{\text {INK4b }}$ have been detected in many mouse tissues, including spleen, lung, brain, heart, liver, colon, and kidney, but those encoding mouse $\mathrm{pl} 6^{\mathrm{INK} 4 \mathrm{a}}$ were only observed in spleen and lung and to a lesser extent in liver even when polymerase chain reactions were used to amplify the same polyadenylated RNAs extracted from these tissues.

Two additional Ink4 family members, $\mathrm{p} 18^{\mathrm{INK} 4 \mathrm{c}}$ and $\mathrm{p} 19^{\mathrm{INK} 4 \mathrm{~d}}$, are also expressed ubiquitously in proliferating cultured cells and in normal mouse tissues (Guan et al. 1994; Hirai et al. 1995). In cultured macrophages and fibroblasts, $\mathrm{p} 19^{\mathrm{INK} 4 \mathrm{~d}} \mathrm{mRNA}$ and protein levels oscillate significantly during the cell cycle, being expressed at a nadir during $G_{1}$ and undergoing abrupt induction as cells enter S phase (Hirai et al. 1995). On the basis of the periodic pattern of $\mathrm{p} 19^{\mathrm{INK} 4 \mathrm{~d}}$ expression in proliferating cells and the failure to detect pl $6^{\text {INK4a }}$ transcripts in many mouse tissues, it may prove that an Ink4 family member such as p19, rather than p16, might function normally to limit the activity of cyclin D-dependent kinases as cells exit $G_{1}$ phase. However, introduction of a vector encoding p19 into mouse NIH-3T3 cells, in leading to constitutive p19 synthesis, inhibits cyclin D1cdk4 activity in vivo and induces $G_{1}$ arrest (Hirai et al. 1995). The dependency of p19 on pRb has not been tested, but it is intriguing that p18, like p16, seems to 
rely on the presence of functional $\mathrm{pRb}$ to arrest the cycle (Guan et al. 1994).

Given that all Ink4 proteins share as yet indistinguishable biochemical properties, why are there so many and how do they contribute individually to cdk4 and cdk6 regulation in vivo? By analogy to the D-type cyclins whose biochemical functions appear to be redundant, the INK4 genes might respond differentially to antiproliferative signals. In addition, their capacity to enter into higher order complexes with cyclin D and cdk4 leaves the possibility open that they make independent contacts with other as yet unidentified cdk-associated proteins. It is of interest that $\mathrm{p} 19^{\mathrm{INK} 4 \mathrm{~d}}$ was cloned in a twohybrid interaction screen using the orphan steroid receptor Nur77 (NGFI-B) as bait (Chan et al. 1995), pointing to possible interactions between pl9 and transcription factors. There is no evidence that Ink4 proteins interact with such proteins in mammalian cells, but in yeast, the cyclin-cdk (Pho80-Pho85) inhibitor Pho81 (Kaffman et al. 1994; K. Schneider et al. 1994) has been reported to contact the transcription factor Pho4 in regulating phosphate metabolism (Hirst et al. 1994), providing a singular precedent.

The ability of p16 and pl 8 to arrest $G_{1}$ progression only in cells containing functional $\mathrm{pRb}$ implies that the loss of Ink4 proteins, like loss of pRb, might similarly predispose cells toward tumor development. Genetic linkage analysis of families with hereditary melanoma localized a putative susceptibility gene to the short arm of human chromosome 9, band p21 (Cannon-Albright et al. 1992|, a relatively frequent site of chromosomal rearrangement and loss of heterozygosity in other sporadic tumors (Kamb et al. 1994a; Nobori et al. 1994, and references therein). The critical region of chromosome $9 \mathrm{p} 21$ includes the tandemly linked INK4a and INK4b genes (designated MTS1 and MTS2, respectively), and the localization of frameshift, nonsense, and missense mutations to INK4a-codin sequences argued that pl6 was likely to be the relevant target (Kamb et al. 1994a; Nobori et al. 1994). Despite some initial skepticism that p16 mutations might be characteristic of established cell lines rather than of primary tumors from patients, a series of reports, some still emerging, now suggest that deletions and mutations involving INK4a occur in many different types of human cancer /Caldas et al. 1994; Hayashi et al. 1994; Hebert et al. 1994; Hussussian et al. 1994; Jen et al. 1994; Kamb et al. 1994b; Mori et al. 1994; Schmidt et al. 1994; Okuda et al. 1995; for review, see Sheaff and Roberts 1995). Particularly compelling are recent findings that several tumor-derived alleles of $I N K 4 a$ containing missense mutations, including ones strongly associated with familial melanoma by genetic linkage analysis and others detected in sporadic carcinomas, encode functionally aberrant pl6 proteins (Lukas et al. 1995b; Renade et al. 1995; Yang et al. 1995). Deletion of INK4 $a$ appears to be restricted to subsets of tumor cells that retain $\mathrm{pRb}$ function and vice versa /see Otterson et al. 1994 for a comprehensive example involving lung cancer), again suggesting that the loss of either gene makes disruption of the other's function irrelevant.
Moreover, in glioblastomas, homozygous INK $4 a$ deletions were detected in $41 \%$ of 46 examined cases, whereas an additional $28 \%$ showed hemizygous deletions (Schmidt et al. 1994). Another subset of cases had amplification of the $c d k 4$ gene, implying that p16 and cdk4 also function in a common regulatory pathway (see Fig. 1). Because $I N K 4 a$ and $I N K 4 b$ are so closely linked that deletions most frequently involve both genes, the loss of both gene products may be significant in the development of certain types of tumors.

The INK4C and INK4d loci map to chromosomes $1 \mathrm{p} 32$ and 19p13, respectively /Guan et al. 1994; Chan et al. 1995; K.L. Guan, C.W. Jenkins, Y. Li, C.L. O'Keefe, S. Noh, X. Wu, M. Zariwala, A.G. Matera, and Y. Xiong, in prep.), and there is as yet no evidence that the product of either gene acts as a tumor suppressor. No deletions or rearrangements of INK4d were observed in blast cells from patients with acute lymphocytic leukemia, many of which $(15 \%-20 \%)$ had sustained homozygous or hemizygous INK4a and $I N K 4 b$ deletions (Okuda et al. 1995). It would be naive to assume that all Ink4 proteins have the capability to act as tumor suppressors, particularly if different family members carry out distinct biologic functions. For example, one such protein (e.g., pl9 ${ }^{\text {INK4d }}$ ) might serve primarily to extinguish cdk4 and cdk6 activity as cycling cells exit $G_{1}$ phase, whereas another (e.g., pl $6^{\text {INK4a }}$ might be expressed normally at relatively low levels in cycling cells but be induced preferentially in response to genotoxic damage, antiproliferative cytokines, or as cells terminally differentiate. Hence, the consequences of their functional inactivation might well be quite different, with the loss of only certain ones being critical in carcinogenesis.

\section{"Avoid running at all times"}

This advice was rendered by Satchell [Leroy] Paige, one of the greatest baseball pitchers of the century, who knew how to martial his extraordinary talents and thereby prolong his career. In his folksy wisdom, he may have inadvertently told us something about cell cycle control.

\section{Acknowledgments}

We thank Drs. Jiri Bartek, David Beach, Anindya Dutta, Stephen Elledge, Edward Harlow, Wade Harper, Phillip Koeffler, James Koh, Andrew Lassar, Jiri Lukas, Joan Massagué, René Medema, Michele Pagano, Steve Reed, Manuel Serrano, Robert Weinberg, Astar Winoto, and Yue Xiong for communicating data before publication.

\section{References}

Ajchenbaum, F., K. Ando, J.A. DeCaprio, and J.D. Griffin. 1993. Independent regulation of human D-type cyclin gene expression during $\mathrm{Gl}$ phase in primary human $\mathrm{T}$ lymphocytes. I. Biol. Chem. 268: 4113-4119.

Baldin, V., J. Lukas, M.J. Marcote, M. Pagano, and G. Draetta. 1993. Cyclin D1 is a nuclear protein required for cell cycle progression in $\mathrm{G}_{1}$. Genes \& Dev. 7: 812-821. 
Bates, S., L. Bonetta, D. Macallan, D. Parry, A. Holder, C. Dickson, and G. Peters. 1994a. CDK6 (PLSTIRE) and CDK4 (PSK$\mathrm{J3}$ ) are a distinct subset of the cyclin-dependent kinases that associate with cyclin D1. Oncogene 9: 71-79.

Bates, S., D. Parry, L. Bonetta, K. Vousden, C. Dickson, and G. Peters. 1994b. Absence of cyclin D/cdk4 complexes in cells lacking functional retinoblastoma protein. Oncogene 9: 1633-1640.

Bullrich, F., T.K. MacLachlan, N. Sang, T. Druck, M.L. Veronese, S.L. Allen, N. Chiorazzi, A. Koff, K. Huebner, C.M. Croce, and A. Giordano. 1995. Chromosomal mapping of members of the cdc2 family of protein kinases, cdk3, cdk6, PISSLRE, and PITALRE, and a cdk inhibitor, p27Kipl, to regions involved in human cancer. Cancer Res. 55: 11991205.

Caelles, C., A. Helmberg, and M. Karin. 1994. p53-Dependent apoptosis in the absence of transcriptional activation of p53target genes. Nature 370: 220-223.

Caldas, C., S.A. Hahn, L.T. da Costa, M.S. Redston, M. Schutte, A.B. Seymour, C.L. Weinstein, R.H. Hruban, C.J. Yeo, and S.E. Kern. 1994. Frequent somatic mutations and homozygous deletions of the p16 (MTS1) gene in pancreatic adenocarcinoma. Nature Genet. 8: 27-32.

Canman, C.E., T.M. Gilmer, S.B. Coutts, and M.B. Kastan. 1995. Growth factor modulation of p53-mediated growth arrest versus apoptosis. Genes \& Dev. 9: 600-611.

Cannon-Albright, L.A., D.E. Goldhar, L.J. Meyer, C.M. Lewis, D.E. Anderson, J.W. Fountain, M.E. Hegi, R.W. Wiseman, E.M. Petty, A.E. Bale, O.I. Olopade, M.O. Diaz, D.J. Kwiatkowski, M.W. Piepkorn, J.J. Zone, and M.H. Skolnick. 1992. Assignment of a locus for familial melanoma, MLM, to chromosome 9p13-p22. Science 258: 1148-1152.

Chan, F.K.M., J. Zhang, L. Chen, D.N. Shapiro, and A. Winoto. 1995. Identification of human/mouse pl9, a novel cdk4/ cdk6 inhibitor with homology to p16 ink4.$M o l$. Cell. Biol. 15: 2682-2688.

Chen, J., P.K. Jackson, M.W. Kirschner, and A. Dutta. 1995. Separate domains of $\mathrm{p} 21$ involved in the inhibition of $\mathrm{cdk}$ kinase and PCNA. Nature 374: 386-388.

Clarke, A.R., E.R. Maandag, M. van Roon, N.M.T. van der Valk, M.L. Hooper, A. Berns, and H. te Reile. 1992. Requirement for a functional RB-1 gene in murine development. Nature 359: 328-330.

Clarke, A.R., C.A. Purdie, D.J. Harrison, R.G. Morris, C.C. Bird, M.L. Hooper, and A.H. Wyllie. 1993. Thymocyte apoptosis induced by p53-dependent and independent pathways. $\mathrm{Na}$ ture 362: 849-852.

Coppola, J.A., B.A. Lewis, and M.D. Cole. 1990. Increased retinoblastoma gene expression is associated with late stages of differentiation in many different cell types. Oncogene 5: 1731-1733.

Debbas, M. and E. White. 1993. Wild-type p53 mediates apoptosis by ElA, which is inhibited by ElB. Genes \& Dev. 7: 546-554.

Di Leonardo A., S.P. Linke, K. Clarkin, and G.M. Wahl. 1994. DNA damage triggers a prolonged p53-dependent $G_{1}$ arrest and long-term induction of Cipl in normal human fibroblasts. Genes \& Dev. 8: 2540-2551.

Dowdy, S.F., P.W. Hinds, K. Louis, S.I. Reed, A. Arnold, and R.A. Weinberg. 1993. Physical interactions of the retinoblastoma protein with human cyclins. Cell 73: 499-511.

Dulic, V., E. Lees, and S.I. Reed. 1992. Association of human cyclin $\mathrm{E}$ with a periodic Gl-S phase protein kinase. Science 257: 1958-1961.

Dulic, V., L.F. Drullinger, E. Lees, S.I. Reed, and G.H. Stein.
1993. Altered regulation of Gl cyclins in senescent human diploid fibroblasts: accumulation of inactive cyclin E-Cdk2 and cyclin Dl-Cdk2 complexes. Proc. Natl. Acad. Sci. 90: $11034-11038$

Dulic, V., W.K. Kaufmann, S.J. Wilson, T.D. Tlsty, E. Lees, J.W. Harper, S.J. Elledge, and S.I. Reed. 1994. p53-Dependent inhibition of cyclin-dependent kinase activities in human fibroblasts during radiation-induced Gl arrest. Cell 76: 10131023.

El-Deiry, W.S., T. Tokino, V.E. Velculescu, D.B. Levy, R. Parsons, J.M. Trent, D. Lin, E. Mercer, K.W. Kinzler, and B. Vogelstein. 1993. WAF1, a potential mediator of p53 tumor suppression. Cell 75: 817-825.

El-Deiry, W.S., J.W. Harper, P.M. O'Connor, V.E. Velculescu, C.E. Canman, J. Jackman, J.A. Pietenpol, M. Burrell, D.E. Hill, Y. Wang, K.G. Wiman, W.E. Mercer, M.B. Kastan, K.W. Kohn, S.J. Elledge, K.W. Kinzler, and B. Vogelstein. 1994. WAF1/Cipl is induced in p53-mediated G1 arrest and apoptosis. Cancer Res. 54: 1169-1174.

Ewen, M.E., H.K. Sluss, C.J. Sherr, H. Matsushime, J. Kato, and D.M. Livingston. 1993a. Functional interactions of the retinoblastoma protein with mammalian D-type cyclins. Cell 73: 487-497.

Ewen, M.E., H.K. Sluss, L.L. Whitehouse, and D.M. Livingston. 1993b. TGF- $\beta$ inhibition of cdk 4 synthesis is linked to cell cycle arrest. Cell 74: 1009-1020.

Ewen, M.E., C.J. Oliver, H.K. Sluss, S.J. Miller, and D.S. Peeper. 1995. p53-dependent repression of CDK4 translation in TGF- $\beta$-induced $G_{1}$ cell-cycle arrest. Genes \& Dev. 9: 204 217.

Firpo, E.J., A. Koff, M.J. Solomon, and J.M. Roberts. 1994. Inactivation of a cdk2 inhibitor during interleukin 2-induced proliferation of human T lymphocytes. Mol. Cell. Biol. 14: 4889-4901.

Fisher, R.P. and D.O. Morgan. 1994. A novel cyclin associates with $\mathrm{MO} 15 / \mathrm{CDK} 7$ to form the CDK-activating kinase. Cell 78: 713-724.

Flores-Rozas, H., Z. Kelman, F.B. Dean, Z. Pan, W.J. Harper, S.J. Elledge, M. O'Donnell, and J. Hurwitz. 1994. Cdk-interacting protein 1 directly binds with proliferating cell nuclear antigen and inhibits DNA replication catalyzed by the DNA polymerase and holoenzyme. Proc. Natl. Acad. Sci. 91: 8655-8659.

Gu, W., J.W. Schneider, G. Condorelli, S. Kaushal, V. Mahdavi, and B. Nadal-Ginard. 1993. Interaction of myogenic factors and the retinoblasoma protein mediates muscle cell commitment and differentiation. Cell 72: 309-324.

Gu, Y., C.W. Turek, and D.O. Morgan. 1993. Inhibition of CDK2 activity in vivo by an associated $20 \mathrm{~K}$ regulatory subunit. Nature 366: 707-710.

Guan, K., C.W. Jenkins, Y. Li, M.A. Nichols, X. Wu, C.L. O'Keefe, A.G. Matera, and Y. Xiong. 1994. Growth suppression by 18 , a p16 $6^{\text {INK4/MTS1 }}$ - and pl $4^{\text {INK4/MTS2 }}$-related CDK6 inhibitor, correlates with wild-type $\mathrm{pRb}$ function. Genes \& Dev. 8: 2939-2952.

Halevy, O., B.G. Novitch, D.B. Spicer, S.X. Skapek, J. Rhee, G.J. Hannon, D. Beach, and A.B. Lasser. 1995. Correlation of terminal cell cycle arrest of skeletal muscle with induction of p21 by MyoD. Science 267: 1018-1021.

Hamel, P.R., A.A. Phillips, M. Muncaster, and B.L. Gallie. 1993. Speculations on the roles of RBl in tissue-specific differentiation, tumor initiation, and tumor progression. FASEB I. 7: 846-854.

Hannon, G.J. and D. Beach. 1994. pl $5^{\mathrm{INK} 4 \mathrm{~b}}$ is a potential effector of cell cycle arrest mediated by TGF- $\beta$. Nature 371:257- 
261.

Harper, J.W., G.R. Adami, N. Wei, K. Keyomarsi, and S.J. Elledge. 1993. The $\mathrm{p} 21 \mathrm{cdk}$-interacting protein $\mathrm{Cipl}$ is a potent inhibitor of Gl cyclin-dependent kinases. Cell 75: 805816.

Harper, J.W., S.J. Elledge, K. Keyomarsi, B. Dynlacht, L.H. Tsai, P. Zhang, S. Dobrowolski, C. Bai, L. Connell-Crowley, E. Swindell, M.P. Fox, and N. Wei. 1995. Inhibition of cyclindependent kinases by p21. Mol. Biol. Cell 6: 387-400.

Hasty, P., A. Bradley, J.H. Morris, D.G. Edmondson, J.M. Venuti, E.N. Olson, and W.H. Klein. 1993. Muscle deficiency and neonatal death in mice with a targeted mutation in the myogenin gene. Nature 364: 501-506.

Hatakeyama, M., J.A. Brill, G.R. Fink, and R.A. Weinberg. 1994. Collaboration of $G_{1}$ cyclins in the functional inactivation of the retinoblastoma protein. Genes \& Dev. 8: 1759-1771.

Hayashi, N., Y. Sugimoto, E. Tsuchiya, M. Ogawa, and Y. Nakamura. 1994. Somatic mutations of the MTS /multiple tumor suppressor) 1/CDK4I (cyclin-dependent kinase-4 inhibitor) gene in human primary non-small cell lung carcinomas. Biochem. Biophys. Res. Commun. 202: 1426-1430.

Hebert, J., J.M. Cayuela, J. Berkeley, and F. Sigaux. 1994. Candidate tumor suppressor MTS1 $\left(\mathrm{p} 16^{\mathrm{INK} 4 \mathrm{~A}}\right)$ and MTS2 $\left(\mathrm{p} 15^{\mathrm{INK} 4 \mathrm{~B}}\right)$ display frequent homozygous deletions in primary cells from $T$ - but not B-cell lineage acute lymphoblastic leukemias. Blood 84: 4038-4044.

Hengst, L., V. Dulic, J.M. Slingerland, E. Lees, and S.I. Reed. 1994. A cell cycle-regulated inhibitor of cyclin-dependent kinases. Proc. Natl. Acad. Sci. 91: 5291-5295.

Hinds, P.W. and R.A. Weinberg. 1994. Tumor suppressor genes. Curr. Opin. Genet. Dev. 4: 135-141.

Hinds, P.W., S. Mittnacht, V. Dulic, A. Arnold, S.I. Reed, and R.A. Weinberg. 1992. Regulation of retinoblastoma protein functions by ectopic expression of human cyclins. Cell 70: 993-1006.

Hirai, H., M.F. Roussel, J. Kato, R.A. Ashmun, and C.J. Sherr. 1995. Novel INK4 proteins, pl9 and p18, are specific inhibitors of cyclin D-dependent kinases CDK4 and CDK6. Mol. Cell. Biol. 15: 2672-2681.

Hirst, K., F. Fisher, P.C. McAndrew, and C.R. Goding. 1994. The transcription factor, the cdk, its cyclin and their regulator: Directing the transcriptional response to a nutritional signal. EMBO I. 13: 5410-5420.

Hunter T. and J. Pines. 1994. Cyclins and cancer. II. cyclin D and CDK inhibitors come of age. Cell 79: 573-582.

Hussussian, C.J., J.P. Struewing, A.M. Goldstein, P.A.T. Higgans, D.S. Ally, M.D. Sheahan, W.H. Clark, M.A. Tucker, and N.C. Dracopoli. 1994. Germline pl6 mutations in familial melanoma. Nature Genet. 8: 15-21.

Jacks, T., A. Faxeli, E.M. Schmitt, R.T. Bronson, M.A. Goodell, and R.A. Weinberg. 1992. Effects of an Rb mutation in the mouse. Nature 359: 295-300.

Jen, J., J.W. Harper, S. Bigner, N. Papadopoulos, S. Markowitz, J. Willson, K. Kinzler, and B. Vogelstein. 1994. Deletion of pl6 and pl5 genes in brain tumors. Cancer Res. 24: 6353-6358.

Jiang, H., J. Lin, Z. Su, F.R. Collart, E. Huberman, and P.B. Fisher. 1994. Induction of differentiation in human promyelocytic HL-60 leukemia cells activates p21, WAF1/CIP1, expression in the absence of p53. Oncogene 9: 3397-3407.

Kaffman, A., I. Herskowitz, R. Tijan, and E.K. O'Shea. 1994. Phosphorylation of the transcription factor PHO4 by a cyclin-CDK complex, PHO80-PH085. Science 263: 1153-1156.

Kamb, A., N.A. Gruis, J. Weaver-Feldhaus, Q. Liu, K. Harshman, S.V. Tavtigian, E. Stockert, R.S. Day III, B.E. Johnson, and M.H. Skolnick. 1994a. A cell cycle regulator involved in genesis of many tumor types. Science 264: 436-440.
Kamb, A., D. Shattuck-Eidens, R. Eeles, Q. Liu, N.A. Gruis, W. Ding, C. Hussey, T. Tran, Y. Miki, J. Weaver-Feldhaus, M. McClure, J.F. Aitken, D.E. Anderson, W. Bergman, R. Frants, D.E. Goldgar, A. Green, R. MacLennan, N.G. Martin, L.J. Meyer, P. Youl, J.J. Zone, M.H. Skolnick, and L.A. CannonAlbright. 1994b. Analysis of the pl 6 gene (CDKN2) as a candidate for the chromosome 9p melanoma susceptibility locus. Nature Genet. 8: 22-26.

Kastan, M.B., O. Onyekwere, D. Sidransky, B. Vogelstein, and R.W. Craig. 1991. Participation of p53 protein in the cellular response to DNA damage. Cancer Res. 51: 6304-6311.

Kastan, M.B., Q. Zhan, W.S. El-Deiry, F. Carrier, T. Jacks, W.V. Walsh, B.S. Plunkett, B. Vogelstein, and A.J. Fornace Jr. 1992. A mammalian cell cycle checkpoint pathway utilizing p53 and GADD45 is defective in ataxia-telangiectasia. Cell 71: $587-597$.

Kato, J. and C.J. Sherr. 1993. Inhibition of granulocyte differentiation by G1 cyclins, D2 and D3, but not D1. Proc. Natl. Acad. Sci. 90: 11513-11517.

Kato, J., H. Matsushime, S.W. Hiebert, M.E. Ewen, and C.J. Sherr. 1993. Direct binding of cyclin D to the retinoblastoma gene product $(\mathrm{pRb})$ and $\mathrm{pRb}$ phosphorylation by the cyclin D-dependent kinase, CDK4. Genes \& Dev. 7: 331-342.

Kato, J., M. Matsuoka, K. Polyak, J. Massagué, and C.J. Sherr. 1994a. Cyclic AMP-induced G1 phase arrest mediated by an inhibitor (p27 $\left.{ }^{\mathrm{Kipl}}\right)$ of cyclin-dependent kinase-4 activation. Cell 79: 487-496.

Kato, J., M. Matsuoka, D.K. Strom, and C.J. Sherr. 1994b. Regulation of cyclin D-dependent kinase 4 (cdk4) by cdk4-activating kinase. Mol. Cell. Biol. 14: 2713-2721.

Knoblich, J.A., K. Sauer, L. Jones, H. Richardson, R. Saint, and C.F. Lehner. 1994. Cyclin E controls S phase progression and its down-regulation during Drosophila embryogenesis and is required for the arrest of cell proliferation. Cell 77: 107-120.

Koff, A., F. Cross, A. Fisher, J. Schumacher, K. Leguellec, M. Philippe, and J.M. Roberts. 1991. Human cyclin E, a new cyclin that interacts with two members of the CDC2 gene family. Cell 66: 1217-1228.

Koff, A., A. Giordano, D. Desai, K. Yamashita, J.W. Harper, S. Elledge, T. Nishimoto, D.O. Morgan, B.R. Franza, and J.M. Roberts. 1992. Formation and activation of a cyclin E-cdk2 complex during the Gl phase of the human cell cycle. Science 257: 1689-1694.

Koff, A., M. Ohtsuki, K. Polyak, J.M. Roberts, and J. Massagué. 1993. Negative regulation of Gl in mammalian cells: Inhibition of cyclin E-dependent kinase by TGF- $\beta$. Science 260: 536-539.

Koi, M., L.A. Johnson, L.M. Kalikan, P.F. Little, Y. Nakamura, and A.P. Feinberg. 1993. Tumor cell growth arrest caused by subchromosomal transferable DNA fragments from chromosome 11. Science 260: 361-364.

Koufos, A., M.F. Hansen, N.G. Copeland, N.A. Jenkins, B.C. Lampkin, and W.K. Cavanee. 1985. Loss of heterozygosity in three embryonal tumours suggests a common pathogenetic mechanism. Nature 316: 330-334.

Kuerbitz, S.J., B.S. Plunkett, W.V. Walsh, and M.B. Kastan. 1992. Wild-type p53 is a cell cycle checkpoint determinant following irradiation. Proc. Natl. Acad. Sci. 89: 7491-7495.

Lee, E.Y., C.Y. Chang, N. Hu, Y.C. Yang, C.C. Lai, K. Herrup, W.H. Lee, and A. Bradley. 1992. Mice deficient for Rb are nonviable and show defects in neurogenesis and haematopoiesis. Nature 359: 288-294.

Lee, M.H., I. Reynisdóttir, and J. Massagué. 1995. Cloning of $\mathrm{p} 57^{\mathrm{KIP} 2}$, a cyclin-dependent kinase inhibitor with unique domain structure and tissue distribution. Genes \& Dev. 9: 639-649. 
Lew, D.J., V. Dulic, and S.I. Reed. 1991. Isolation of three novel human cyclins by rescue of $\mathrm{Gl}$ cyclin (Cln) function in yeast. Cell 66: 1197-1206.

Li, R., S. Waga, G.J. Hannon, D. Beach, and B. Stillman. 1994. Differential effects by the p21 CDK inhibitor on PCNA dependent DNA replication and repair. Nature 371: 534-537.

Li, Y., C.W. Jenkins, M.A. Nichols, and Y. Xiong. 1994. Cell cycle expression and p53 regulation of the cyclin-dependent kinase inhibitor p21. Oncogene 9: 2261-2268.

Livingstone, L.R., A. White, J. Sprouse, E. Livanos, T. Jacks, and T.D. Tlsty. 1992. Altered cell cycle arrest and gene amplification potential accompany loss of wild-type p53. Cell 70: $923-935$.

Lotem, J. and L. Sachs. 1993. Hematopoietic cells from mice deficient in wild-type p53 are more resistant to induction of apoptosis by some agents. Blood 82: 1092-1096.

Lowe, S.W., E.M. Schmitt, S.W. Smith, B. Osborne, and T. Jacks. 1993. p53 is required for radiation-induced apoptosis in mouse thymocytes. Nature 362: 847-849.

Lowe, S.W., T. Jacks, D. Housman, and E.H. Ruley. 1994. Abrogation of oncogene-associated apoptosis allows transformation of p53-deficient cells. Proc. Natl. Acad. Sci. 91: 2026-2030.

Lu, X. and D.P. Lane. 1993. Differential induction of transcriptionally active p53 following UV or ionizing radiation: Defects in chromosome instability syndromes? Cell 75: 765778.

Lukas, J., H. Muller, J. Bartkova, D. Spitkovsky, A.A. Kjerulff, P. Jansen-Durr, M. Strauss, and J. Bartek. 1994. DNA tumor virus oncoproteins and retinoblastoma gene mutations share the ability to relieve the cell's requirement for cyclin Dl function in G1. I. Cell Biol. 125: 625-638.

Lukas, J., J. Bartkova, M. Rohde, M. Strauss, and J. Bartek. 1995a. Cyclin D1 is dispensable for Gl control in retinoblastoma gene-deficient cells, independent of CDK4 activity. Mol. Cell. Biol. 15: 2600-2611.

Lukas, J., D. Parry, L. Aagaard, D.J. Mann, J. Bartkova, M. Strauss, G. Peters, and J. Bartek. 1995b. Retinoblastoma protein-dependent cell-cycle inhibition by the tumour suppressor pl6. Nature (in press).

Luo, Y., J. Hurwitz, and J. Massagué. 1995. Cell cycle inhibition mediated by functionally independent CDK and PCNA inhibitory domains in $\mathrm{p}^{\mathrm{CIP1}}$. Nature (in press).

Makela, T.P., J.P. Tassan, E.A. Nigg, S. Frutiger, G.J. Hughes, and R.A. Weinberg. 1994. A cyclin associated with the cdkactivating kinase MOl5. Nature 371: 254-257.

Martinez, J., I. Georgoff, and A.J. Levine. 1991. Cellular localization and cell cycle regulation by a temperature-sensitive p53 protein. Genes \& Dev. 5: 151-159.

Matsuoka, M., J. Kato, R.P. Fisher, D.O. Morgan, and C.J. Sherr. 1994. Activation of cyclin-dependent kinase-4 (CDK4) by mouse MO15-associated kinase. Mol. Cell. Biol. 14: 72657275.

Matsuoka, S., M. Edwards, C. Bai, S. Parker, P. Zhang, A. Bal-

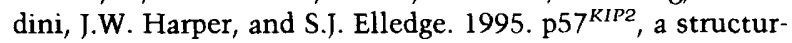
ally distinct member of the $\mathrm{p} 21^{C I P 1} \mathrm{cdk}$ inhibitor family, is a candidate tumor suppressor gene. Genes \& Dev. 9:650-662.

Matsushime, H., M.F. Roussel, R.A. Ashmun, and C.J. Sherr. 1991. Colony-stimulating factor 1 regulates novel cyclins during the G1 phase of the cell cycle. Cell 65: 701-713.

Matsushime, H., M.E. Ewen, D.K. Strom, J. Kato, S.K. Hanks, M.F. Roussel, and C.J. Sherr. 1992. Identification and properties of an atypical catalytic subunit (p34 ${ }^{\text {PSKJ3 }} /$ CDK4) for mammalian D-type Gl cyclins. Cell 71: 323-334.

Matsushime, H., D.E. Quelle, S.A. Shurtleff, M. Shibuya, C.J. Sherr, and J. Kato. 1994. D-type cyclin-dependent kinase ac- tivity in mammalian cells. Mol. Cell. Biol. 14: 2066-2076.

Medema, R., R.E. Herrera, F. Lam, and R.A. Weinberg. 1995. Growth suppression by $\mathrm{p} 16^{\mathrm{INK} 4}$ requires functional retinoblastoma protein. Proc. Natl. Acad. Sci. (in press).

Meyerson, M. and E. Harlow. 1994. Identification of a Gl kinase activity for cdk6, a novel cyclin D partner. Mol. Cell. Biol. 14: 2077-2086.

Michieli, P., M. Chedid, D. Lin, J.H. Pierce, W.E. Mercer, and D. Givol. 1994. Inhibition of WAF1/CIP1 by a p53-independent pathway. Cancer Res. 54: 3391-3395.

Modiano, J.F., J. Domenico, A. Szepesi, J.J. Lucas, and E.W. Gelfand. 1994. Differential requirements for interleukin-2 distinguish the expression and activity of the cyclin-dependent kinases cdk4 and cdk42 in human T cells. J. Biol. Chem. 52: 32972-32978.

Morgenbesser, S.D., B.O. Williams, T. Jacks, and R.A. DePinho. 1994. p53-dependent apoptosis produced by Rb-deficiency in the developing mouse lens. Nature 371: 72-74.

Mori, T., K. Miura, T. Aoki, T. Nishihira, N. Shozo, and Y. Nakamura. 1994. Frequent somatic mutation of the MTS1/ CDK4I /multiple tumor suppressor/cyclin-dependent kinase 4 inhibitor) gene in esophageal squamous cell carcinoma. Cancer Res. 54: 3396-3397.

Müller, H., I. Lukas, A. Schneider, P. Warthoe, I. Bartek, M. Eilers, and M. Strauss. 1994. Cyclin Dl expression is regulated by the retinoblastoma protein. Proc. Natl. Acad. Sci. 91: 2945-2949.

Nakanishi, M., R.S. Robetorge, G.R. Adami, O.M. PereiraSmith, and J.R. Smith. 1995. Identification of the active region of the DNA synthesis inhibitory gene $\mathrm{p} 21^{\text {Sdil/CIP1/WAF1. }}$ $E M B O$ I. 14: 555-563.

Nevins, J.R. 1992. E2F: A link between the Rb tumor suppressor protein and viral oncoproteins. Science 258: 424-429.

Nobori, T., K. Miura, D.J. Wu, A. Lois, K. Takabayashi, and D.A. Carson. 1994. Deletions of the cyclin-dependent kinase-4 inhibitor gene in multiple human cancers. Nature 368: 753756.

Noda, A., Y. Ning, S.F. Venable, O.M. Pereira-Smith, and J.R. Smith. 1994. Cloning of senescent cell-derived inhibitors of DNA synthesis using an expression screen. Exp. Cell Res. 211: $90-98$.

Nourse, J., E. Firpo, W.M. Flanagan, S. Coats, K. Polyak, M.H. Lee, J. Massagué, G. Crabtree, and J. Roberts. 1994. Interleukin-2-mediated elimination of $\mathrm{p} 27^{\mathrm{Kip} 1}$ cyclin-dependent kinase inhibitor prevented by rapamycin. Nature 372: 570 573.

Ohtsubo, M. and J.M. Roberts. 1993. Cyclin-dependent regulation of G1 in mammalian fibroblasts. Science 259: 19081912.

Ohtsubo, M., A.M. Theodoras, J. Schumacher, J.M. Roberts, and M. Pagano. 1995. Human cyclin E, a nuclear protein essential for the G1 to S phase transition. Mol. Cell. Biol. 15: 2612-2624.

Okamoto, A., D.J. Demetrick, E.A. Spillare, K. Hagiwara, S.P. Hussain, W.P. Bennett, K. Forrester, B. Gerwin, M. Serrano, D.H. Beach, and C.C. Harris. 1994. Mutations and altered expression of pl6 $6^{\mathrm{INK} 4}$ in human cancer. Proc. Natl. Acad. Sci. 91: 11045-11049.

Okuda, T., S.A. Shurtleff, M.B. Valentine, S.C. Raimondi, D.R. Head, F. Behm, A.M. Curcio-Brint, Q. Liu, C.H. Pui, C.J. Sherr, D. Beach, A.T. Look, and J.R. Downing. 1995. Frequent deletion of $\mathrm{p} 16^{\mathrm{INK} 4 \mathrm{a}} / \mathrm{MTS} 1$ and $\mathrm{p} 15^{\mathrm{INK} 4 \mathrm{~b}} / \mathrm{MTS} 2$ in pediatric acute lymphoblastic leukemia. Blood 85: 2321-2330.

Otterson, G.A., R.A. Kratzke, A. Coxon, Y.W. Kim, and F.J. Kaye. 1994. Absence of pl6 $6^{\text {INK4 }}$ protein is restricted to the subset of lung cancer lines that retains wildtype RB. Onco- 
gene 9: 3375-3378.

Pan, H. and A.E. Griep. 1994. Altered cell cycle regulation in the lens of HPV-16 E6 or E7 transgenic mice: Implications for tumor suppressor gene function in development. Genes \& Dev. 8: 1285-1299.

Pardee, A.B. 1989. G1 events and regulation of cell proliferation. Science 246: 603-608.

Parker, S.B., G. Eichele, P. Zhang, A. Rawls, A.T. Sands, A. Bradley, E.N. Olson, J.W. Harper, and S.J. Elledge. 1995. p53independent expression of $\mathrm{p} 21^{\mathrm{CIP} 1}$ in muscle and other terminally differentiating cells. Science 267: 1024-1027.

Parry, D., S. Bates, D.J. Mann, and G. Peters. 1995. Lack of cyclin D-cdk complexes in Rb-negative cells correlates with high levels of $\mathrm{p} 16^{\mathrm{INK} 4 / \mathrm{MTS1}}$ tumor suppressor gene product. EMBO I. 14: 503-511.

Peters, G. 1994. Cell cycle: Stifled by inhibitions. Nature 371: 204-205.

Pietenpol, J., S. Bohlander, Y. Sata, B. Papadoupolos, C. Liu, B. Friedman, B.J. Trask, J.M. Roberts, K. Kinzler, J. Rowley, and B. Vogelstein. 1995. Assignment of the human p27Kipl gene to $12 \mathrm{p} 13$ and its analysis in leukemias. Cancer Res. 55: $1206-1210$.

Pines, J. 1993. Cyclins and cyclin-dependent kinases: Take your partners. Trends Biochem. Sci. 18: 195-197.

Polyak, K., J. Kato, M.J. Solomon, C.J. Sherr, J. Massagué, J.M. Roberts, and A. Koff. 1994a. p2 $7^{\text {Kipl }}$, a cyclin-cdk inhibitor, links transforming growth factor $-\beta$ and contact inhibition to cell cycle arrest. Genes \& Dev. 8: 9-22.

Polyak, K., M. Lee, H. Erdjument-Bromage, A. Koff, J.M. Roberts, P. Tempst, and J. Massagué. 1994b. Cloning of p $27^{\mathrm{Kipl}}$, a cyclin-dependent kinase inhibitor and a potential mediator of extracellular antimitogenic signals. Cell 78: 59-66.

Ponce-Castaneda, M., M.H. Lee, K. Polyak, L. Lancombe, K. Montgomery, S. Matnew, K. Krauter, J. Schinfeld, J. Massagú, and C. Cordon-Cardo. 1995. p27Kipl chromosomal mapping to $12 \mathrm{p} 12$ and absence of mutations in human tumors. Cancer Res. 55: 1211-1214.

Qin, X.Q., D.M. Livingston, W.G. Kaelin Jr., and P.D. Adams. 1994. Deregulated transcription factor E2F-1 expression leads to S-phase entry and p53-mediated apoptosis. Proc. Natl. Acad. Sci. 91: 10918-10922.

Quelle, D.E., R.A. Ashmun, S.A. Shurtleff, J. Kato, D. Bar-Sagi, M.F. Roussel, and C.J. Sherr. 1993. Overexpression of mouse D-type cyclins accelerates $G_{1}$ phase in rodent fibroblasts. Genes \& Dev. 7: 1559-1571.

Ranade, K., C.J. Hussassian, R.S. Sikorski, H.E. Varmus, A.M. Goldstein, M.A. Tucker, M. Serrano, G.J. Hannon, D. Beach, and N.C. Dracopoli. 1995. Mutations associated with familial melanoma impair p16 $6^{\mathrm{INK} 4}$ function. Nature Genet. (in press\}.

Rao, S.S., C. Chu, and D.S. Kohtz. 1994. Ectopic expression of cyclin D1 prevents activation of gene transcription by myogenic basic-loop-helix regulators. Mol. Cell. Biol. 14: 52595267.

Resnitzky, D. and S. Reed. 1995. Different roles for cyclins Dl and $\mathrm{E}$ in regulation of the $\mathrm{G} 1$ to $\mathrm{S}$ transition. Mol. Cell. Biol. (in press).

Resnitzky, D., M. Gossen, H. Bujard, and S.I. Reed. 1994. Acceleration of the Gl/S phase transition by expression of cyclins D1 and E with an inducible system. Mol. Cell. Biol. 14: 1669-1679.

Schmidt, E.E., K. Ichimura, G. Reifenberger, and V.P. Collins. 1994. CDKN2 (p16/MTS1) gene deletion or CDK4 amplification occurs in the majority of glioblastomas. Cancer Res. 54: 6321-6324.

Schneider, J.W., W. Gu, L. Zhu, V. Mahdavi, and B. Nadal-Gi- nard. 1994. Reversal of terminal differentiation mediated by p107 in $\mathrm{Rb}^{-1-}$ muscle cells. Science 264: 1467-1469.

Schneider, K.R., R.L. Smith, and E.K. O'Shea. 1994. Phosphateregulated inactivation of the kinase PHO80-PHO85 by the CDK inhibitor PHO81. Science 266: 122-126.

Serrano, M., G.J. Hannon, and D. Beach. 1993. A new regulatory motif in cell cycle control causing specific inhibition of cyclin D/cdk4. Nature 366: 704-707.

Serrano, M., E. Gomez-Lahoz, R.A. DePinho, D. Beach, and D. Bar-Sagi. 1995. Inhibition of ras-induced proliferation and cellular transformation by p16 ${ }^{\mathrm{INK} 4}$. Science 267: 249-252.

Sheaff, R.J. and J.M. Roberts. 1995. Lessons in pl 6 from phylum Falconium. Curr. Biol. 5: 28-31.

Sheikh, M.D., X. Li, J. Chen, Z. Shao, J.V. Ordonez, and J.A. Fontana. 1994. Mechanisms of regulation of WAFl/Cipl gene expression in human breast carcinoma: Role of p53dependent and independent signal transduction pathways. Oncogene 9: 3407-3415.

Sherr, C.J. 1993. Mammalian $G_{1}$ cyclins. Cell 73: 1059-1065.

. 1994a. Gl phase progression: Cycling on cue. Cell 79: $551-555$

-1994b. The ins and outs of RB: Coupling gene expression to the cell cycle clock. Trends Cell Biol. 4: 15-18.

Shivii, M.K.K., S.J. Grey, U.P. Strausfeld, R.D. Wood, and J.J. Blow. 1994. Cip1 inhibits DNA replication but not PCNAdependent nucleotide excision-repair. Curr. Biol. 4: 10621068.

Skapek, S.X., J. Rhee, D.B. Spicer, and A.B. Lassar. 1995. Inhibition of myogenic differentiation in proliferating myoblasts by cyclin D-dependent kinase. Science 267: 1022-1024.

Slebos, R.J.C., M.H. Lee, B.S. Plunkett, T.D. Kessis, B.O. Williams, T. Jacks, L. Hedrick, M.B. Kastan, and K.R. Cho. 1994. p53-dependent G1 arrest involves pRB-related proteins and is disrupted by the human papillomavrus 16 E7 oncoprotein. Proc. Natl. Acad. Sci. 91: 5320-5324.

Slingerland, J.M., L. Hengst, C.H. Pan, D. Alexander, M.F. Stampfer, and S.I. Reed. 1994. A novel inhibitor of cyclin-cdk activity detected in transforming growth factor $\beta$-arrested epithelial cells. Mol. Cell. Biol. 14: 3683-3694.

Steinman, R.A., B. Hoffman, A. Iro, C. Guillouf, D.A. Lieberman, and M.E. EL-Houseini. 1994. Induction of p21(WAF-1/ CIP1) during differentiation. Oncogene 9: 3389-3396.

Strausfeld, U.P., M. Howell, R. Rempel, J.L. Maller, T. Hunt, and J.J. Blow. 1994. Cipl blocks the initiation of DNA replication in Xenopus extracts by inhibition of cyclin-dependent kinases. Curr. Biol. 4: 876-883.

Symonds, H., L. Krall, L. Remington, M. Saenz-Robles, S. Lowe, T. Jacks, and T. Van Dyke. 1994. p53-dependent apoptosis suppresses tumor growth and progression in vivo. Cell 78: 703-711.

Tam, S.W., J.W. Shay, and M. Pagano. 1994a. Differential expression and cell cycle regulation of the cyclin-dependent kinase 4 inhibitor pl6 ${ }^{\text {INK4 }}$. Cancer Res. 54: 5816-5820.

Tam, S.W., A.M. Theodoras, J.W. Shay, G.F. Draetta, and M. Pagano. 1994b. Differential expression and regulation of cyclin Dl protein in normal and tumor human cells: Association with cdk4 is required for cyclin D1 function in G1 progression. Oncogene 9: 2663-2674.

Thorburn, A.M., P.A. Walton, and J.R. Feramisco. 1993. MyoD induced cell cycle arrest is associated with increased nuclear affinity of the Rb protein. Mol. Biol. Cell. 4: 705-713.

Toyoshima, H. and T. Hunter. 1994. p27, a novel inhibitor of G1 cyclin/cdk protein kinase activity, is related to p21. Cell 78: $67-74$.

van den Heuvel, S. and E. Harlow. 1993. Distinct roles for cyclin-dependent kinases in cell cycle control. Science 
262: 2050-2054.

Waga, S., G.J. Hannon, D. Beach, and B. Stillman. 1994. The p21 inhibitor of cyclin-dependent kinases controls DNA replication by interaction with PCNA. Nature 369: 574-578.

Wagner, A.J., J.M. Kokontis, and N. Hay. 1994. Myc-mediated apoptosis requires wild-type p53 in a manner independent of cell cycle arrest and the ability of p53 to induce p $21^{\text {waf } 1 / \text { cip } 1}$. Genes \& Dev. 8: 2817-2830.

Warbrick, E., D.P. Lane, D.M. Glover, and L.S. Cox. 1995. A small peptide inhibitor of DNA replication defines the site of interaction between the cyclin-dependent kinase inhibitor $\mathrm{p} 21^{\mathrm{WAF} 1}$ and proliferating cell nuclear antigen. Curr. Biol. 5: 275-282.

Weinberg, R.A. 1991. Tumor suppressor genes. Science 254: 1138-1146.

Wu, X. and A.J. Levine. 1994. p53 and E2F-1 cooperate to mediate apoptosis. Proc. Natl. Acad. Sci. 91: 3602-3606.

Xiong, Y., H. Zhang, and D. Beach. 1992. D-type cyclins associate with multiple protein kinases and the DNA replication and repair factor PCNA. Cell 71: 505-514.

1993a. Subunit rearrangement of the cyclin-dependent kinases is associated with cellular transformation. Genes \& Dev. 7: 1572-1583.

Xiong, Y., G.J. Hannon, H. Zhang, D. Casso, R. Kobayashi, and D. Beach. 1993b. p21 is a universal inhibitor of cyclin kinases. Nature 366: 701-704.

Yang, R., M. Serrano, and P. Koeffler. 1995. Mutational effects of the pl $6^{\mathrm{INK} 4 \mathrm{a}}$ tumor supressor protein. Cancer Res. (in press).

Yin, Y., M.A. Tainsky, F.Z. Bischoff, L.C. Strong, and G.M. Wahl. 1992. Wild-type p53 restores cell cycle control and inhibits gene amplification in cells with mutant p53 alleles. Cell 70: 937-948.

Yonish-Rouach, E., D. Resnitzky, J. Lotem, L. Sachs, A. Kimchi, and M. Oren. 1991. Wild-type p53 induces apoptosis of myeloid leukemic cells that is inhibited by interleukin-6. $\mathrm{Na}$ ture 352: 345-347.

Zhang, H., Y. Xiong, and D. Beach. 1993. Proliferating cell nuclear antigen and $\mathrm{p} 21$ are components of multiple cell cycle kinase complexes. Mol. Biol. Cell 4: 897-906.

Zhang, H., G.J. Hannon, and D. Beach. 1994. p21-containing cyclin kinases exist in both active and inactive states. Genes \& Dev. 8: 1750-1758. 


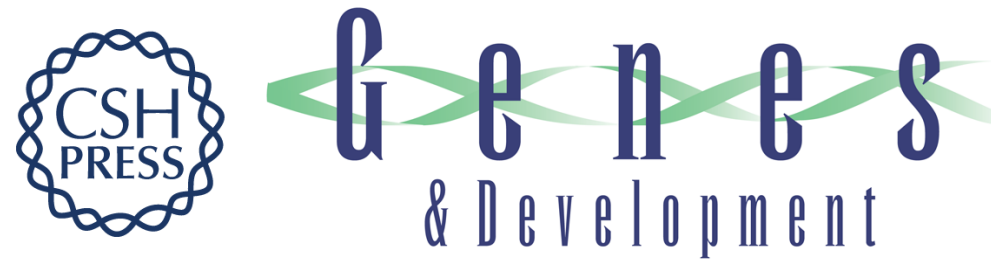

\section{Inhibitors of mammalian G1 cyclin-dependent kinases.}

C J Sherr and J M Roberts

Genes Dev. 1995, 9:

Access the most recent version at doi:10.1101/gad.9.10.1149 $\begin{array}{ll}\text { References } & \text { This article cites } 149 \text { articles, } 75 \text { of which can be accessed free at: } \\ \text { http://genesdev.cshlp.org/content/9/10/1149.full.html\#ref-list-1 }\end{array}$

License

Email Alerting

Receive free email alerts when new articles cite this article - sign up in the box at the top Service right corner of the article or click here.

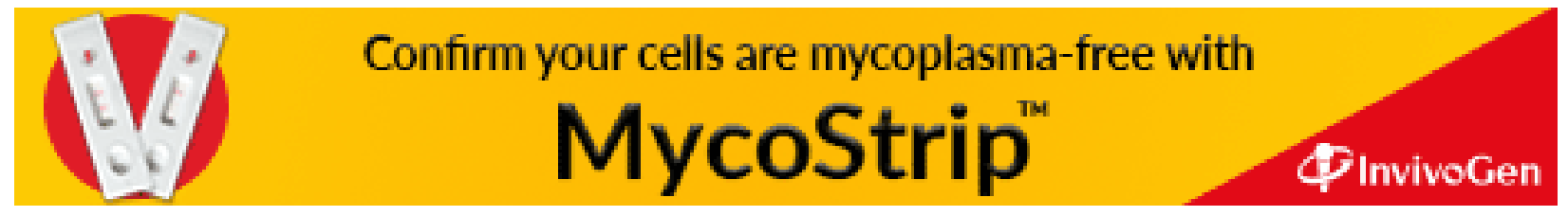

